\title{
Pattern of recurrence of early breast cancer is different according to intrinsic subtype and proliferation index
}

Nuria Ribelles ${ }^{1}$, Lidia Perez-Villa², Jose Manuel Jerez³ ${ }^{3}$ Bella Pajares ${ }^{1}$, Luis Vicioso², Begoña Jimenez ${ }^{1}$, Vanessa de Luque ${ }^{1}$, Leonardo Franco ${ }^{3}$, Elena Gallego ${ }^{2}$, Antonia Marquez ${ }^{1}$, Martina Alvarez ${ }^{4}$, Alfonso Sanchez-Muñoz ${ }^{1}$, Luis Perez-Rivas ${ }^{1}$ and Emilio Alba ${ }^{1 *}$

\begin{abstract}
Introduction: Recurrence risk in breast cancer varies throughout the follow-up time. We examined if these changes are related to the level of expression of the proliferation pathway and intrinsic subtypes.

Methods: Expression of estrogen and progesterone receptor, Ki-67, human epidermal growth factor receptor 2 (HER2), epidermal growth factor receptor (EGFR) and cytokeratin 5/6 (CK 5/6) was performed on tissue-microarrays constructed from a large and uniformly managed series of early breast cancer patients $(N=1,249)$. Subtype definitions by four biomarkers were as follows: luminal A (ER + and/or PR+, HER2-, Ki-67 <14), luminal B (ER + and/or PR+, HER2-,

Ki-67 214), HER2-enriched (any ER, any PR, HER2+, any Ki-67), triple-negative (ER-, PR-, HER2-, any Ki-67). Subtype definitions by six biomarkers were as follows: luminal A (ER + and/or PR+, HER2-, Ki-67 <14, any CK 5/6, any EGFR), luminal B (ER + and/or PR+, HER2-, Ki-67 $\geq 14$, any CK 5/6, any EGFR), HER2-enriched (ER-, PR-, HER2+, any Ki-67, any CK 5/6, any EGFR), Luminal-HER2 (ER + and/or PR+, HER2+, any Ki-67, any CK 5/6, any EGFR), Basal-like (ER-, PR-, HER2-, any Ki-67, CK5/6+ and/or EGFR+), triple-negative nonbasal (ER-, PR-, HER2-, any Ki-67, CK 5/6-, EGFR-). Each four- or six-marker defined intrinsic subtype was divided in two groups, with $\mathrm{Ki}-67<14 \%$ or with Ki-67 $\geq 14 \%$. Recurrence hazard rate function was determined for each intrinsic subtype as a whole and according to Ki-67 value.
\end{abstract}

Results: Luminal A displayed a slow risk increase, reaching its maximum after three years and then remained steady. Luminal B presented most of its relapses during the first five years. HER2-enriched tumors show a peak of recurrence nearly twenty months post-surgery, with a greater risk in Ki-67 $\geq 14 \%$. However a second peak occurred at 72 months but the risk magnitude was greater in Ki-67 $<14 \%$. Triple negative tumors with low proliferation rate display a smooth risk curve, but with Ki-67 $\geq 14 \%$ show sharp peak at nearly 18 months.

Conclusions: Each intrinsic subtype has a particular pattern of relapses over time which change depending on the level of activation of the proliferation pathway assessed by Ki-67. These findings could have clinical implications both on adjuvant treatment trial design and on the recommendations concerning the surveillance of patients.

\footnotetext{
*Correspondence: ealbac@uma.es

'Department of Medical Oncology, Hospital Universitario Virgen de la

Victoria, Campus Teatinos s/n, 29010 Málaga, Spain

Full list of author information is available at the end of the article
} 


\section{Introduction}

The definition of the genomic intrinsic subtypes of breast cancer has been established as the best explanation for the heterogeneous patient outcomes [1-3]. In their original paper, Perou et al. [1] found that the genes that differ most between the intrinsic subtypes (luminal A, luminal B, human epidermal growth factor receptor 2 (HER2)-enriched, basal-like and normal-like) were those within the proliferation cluster. In this respect, a metaanalysis of publicly available breast cancer gene expression data, including those from several published prognostic signatures, revealed that more than $70 \%$ of the genes associated with patient survival were correlated with the proliferation pathway, whereas $26 \%$ were related to estrogen receptor (ER) signaling and $2 \%$ to ERBB2 amplification [4]. The expression of ESR1- and ERBB2related genes showed a bimodal distribution; however, this pattern was not observed in proliferative genes. The expression of genes related to proliferation was constitutively high in ER-/HER2- and ER-/HER2+ tumors. However, in ER+/HER2+ tumors, proliferation gene expression occurred along a continuum with a wide range of values from low in relation to that of normal breast tissues to the high values observed in ER-/HER2- or ER-/HER2+ tumors [4]. These data were corroborated by the same group in a later analysis that included more than twice the number of public breast cancer microarrays data sets [5], contributing to the robustness of their findings.

Currently, the applicability of gene expression profiling in clinical practice is extremely limited for technical and economic reasons. Several studies have shown that breast carcinomas can be stratified into subtypes with different prognoses and treatment responses, similarly to those defined by the genomic portraits, using a set of four [6-10] or six [11-15] immunohistochemical markers, including the assessment of a proliferation marker such as Ki-67 in both definitions.

Together with classic prognostic factors, the intrinsic subtype data provide information with which to appraise the total recurrence risk for a given patient. In designing a therapeutic strategy to prevent disease recurrence, however, it is necessary not only to know the total risk of relapse but also likely to ascertain when recurrence is most likely to occur and when the risk becomes minimal. This knowledge could help to establish at what time the administration of adjuvant treatment will be more effective, which should be taken into consideration when developing new adjuvant strategies. There are enough data on the time-varying recurrence risk obtained through analysis using hazard rate functions to support this decisionmaking. Different authors have described the maximum peak of recurrence risk at 12 to 24 months after surgery [16-22] and the occurrence of a second peak at approximately the fifth year in some cases $[17,18,20,22]$.
In this study, we investigated the importance of the proliferation pathway in the behavior of breast cancer intrinsic subtypes using different statistical approaches. We applied two intrinsic subtype definitions using a set of four or six immunohistochemical markers in a series of early breast cancer patients consecutively treated in a single institution. We also divided every intrinsic subtype according to the level of expression of Ki-67, except in luminal A and luminal B subtypes, because in these cases the Ki-67 expression levels are low and high, respectively, by definition. We hypothesized that a more detailed analysis of the recurrence risk using a hazard rate function methodology would be able to detect differences in such risk over time, depending on the level of expression of the proliferation pathway, even in those subtypes such as HER2-enriched or triple-negative.

\section{Methods}

\section{Study population}

Patients referred to our department were included prospectively in a controlled database. A filtered search was performed to identify stages I to III breast cancer patients enrolled from January 1982 to December 2008. We identified 3,329 patients with stages I to III breast cancer. Nearly $50 \%(n=1,652)$ were referred from other centers; consequently, no tumor samples were available. We excluded 135 patients for various reasons, and, among the remaining 1,542 patients, there were no representative tumor samples in 293 cases (19\%). Therefore, 1,249 patients were definitively included in the study (Figure 1).

The patients were uniformly treated according to clinical guidelines. Briefly, the chemotherapy regimens used during the 1980s were cyclophosphamide, methotrexate and fluorouracil (CMF); during the 1990s, they were anthracycline-based; and thereafter therapy was anthracycline plus taxane-based. Fifty-seven percent of the patients received adjuvant chemotherapy (CMF, 27.4\%; anthracycline-based, 45.9\%; taxanes with or without anthracyclines, 25.1\%; and unknown 1.6\%). Endocrine therapy was administered in 883 patients (luteinizing hormone-releasing hormone analogues plus tamoxifen, 4.5\%; tamoxifen, $66.9 \%$; tamoxifen followed by aromatase inhibitor, 19.6\%; and aromatase inhibitor 8.9\%). Eighteen patients received adjuvant trastuzumab.

Patients underwent follow-up at 6-month intervals during the first 4 years and annually thereafter. Clinicopathological and follow-up information was obtained by chart review.

The study was approved by the Hospital Universitario Virgen de la Victoria Clinical Research Ethics Committee and by the Fondo de Investigaciones Sanitarias from the Ministry of Science and Innovation of Spain under the title "Study of time distribution of recurrence for 


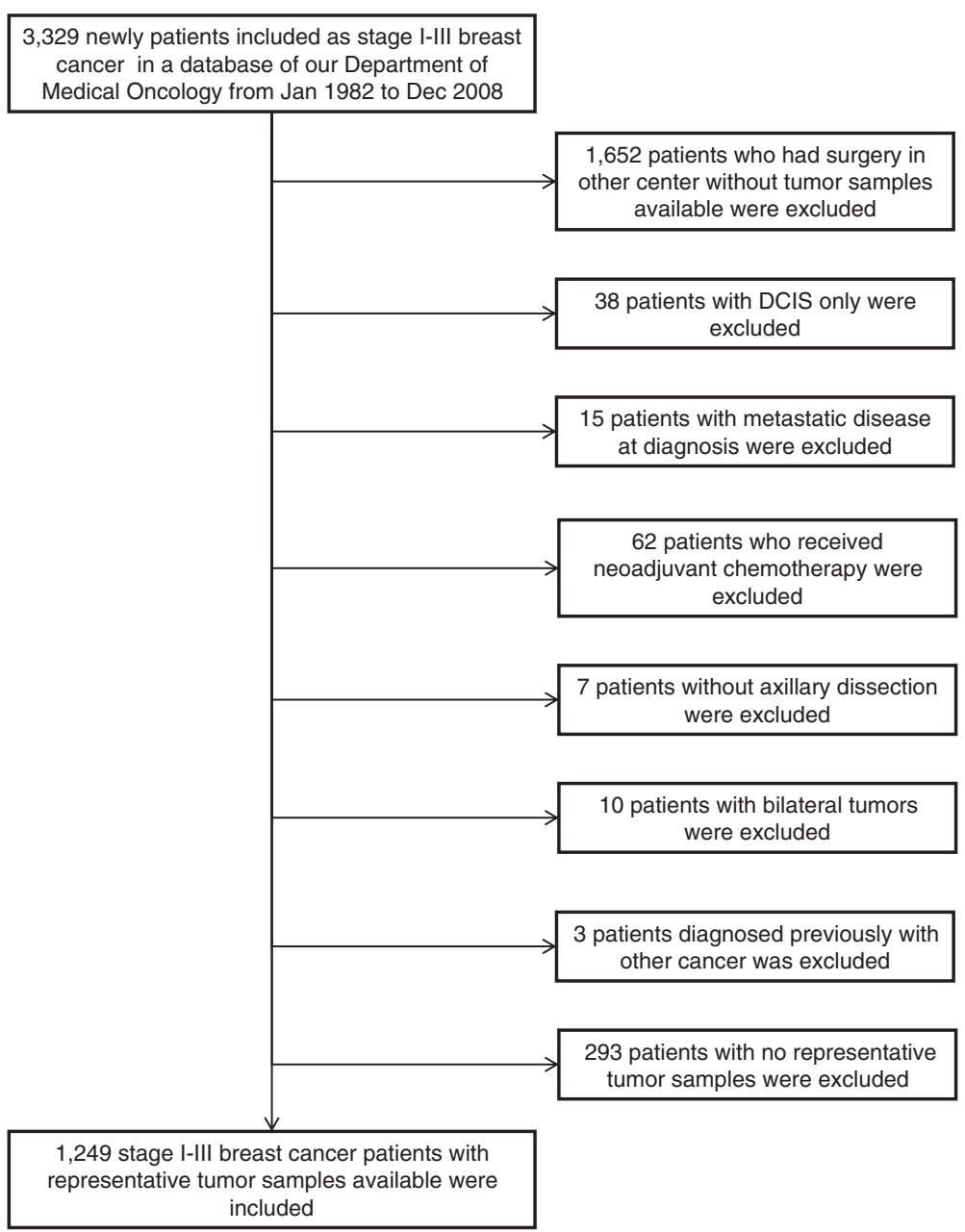

Figure 1 Flow diagram of the patients through the study. DCIS, ductal carcinoma in situ.

breast cancer intrinsic subtypes" (PI081797). Informed consent was obtained from patients whose data have been included in this study, except in those cases where the patient had died, in which event the mentioned ethics committees waived the need to obtain informed consent.

\section{Tissue microarrays and immunohistochemistry}

Archival tumor specimens were retrieved, and hematoxylin and eosin sections from each block were reviewed by a pathologist to select representative tumor tissue areas. Tissue microarrays were constructed, and the cases were represented in triplicate with samples from $0.6-\mathrm{mm}$ cores. Immunohistochemical staining was performed for ER (clone SP1; Master Diagnóstica, Granada, Spain), progesterone receptor (PR) (clone Y85; Master Diagnóstica), human epidermal growth factor receptor 2 (HER2) (HercepTest; Dako, Glostrup, Denmark), Ki-67 (clone SP6; Master Diagnóstica), epidermal growth factor receptor (EGFR) (clone EP38Y; Master Diagnóstica) and cytokeratin types 5 and 6 (CK5/6) (clone D5/16B4; Master Diagnóstica). Staining and interpretation of ER, PR, HER2, Ki-67, EGFR and CK5/6 were performed as previously described [23-26]. ER and PR positivity were defined as immunostaining of more than $1 \%$ of tumor nuclei. Tumors were considered positive for HER2 if immunostaining was scored as $3+$ according to HercepTest criteria. All cases with ambiguous expression of HER2 (HercepTest score 2+) were evaluated by chromogenic in situ hybridization (CISH), and an amplification ratio of 2.0 or more was considered as a positive result (HER2 CISH pharmDx; Dako). Ki-67 was visually scored for percentage of tumor cell nuclei with positive immunostaining above the background level. EGFR and CK5/6 stains were considered positive if any (weak or strong) cytoplasmic and/ or membranous invasive carcinoma cell staining was observed. Tissue microarrays were scored by two pathologists blinded to the clinicopathological characteristics and 
outcomes of each patient. The definition of positivity for each of the biomarkers analyzed and the categorization of intrinsic subtypes according to the four or six immunohistochemical variables are summarized in Table 1. The Ki-67 cutoff used was that defined by Cheang et al. [12].

\section{Statistical analysis methods}

The variables analyzed included age, tumor size, histological grade, lymph node status, local therapy, administration of adjuvant chemotherapy, use of adjuvant hormone therapy and intrinsic subtype defined by the four or six biomarkers. The endpoint was breast cancerfree survival (BCFS), defined as the time from surgery until a local, regional or distant recurrence, a second contralateral tumor or death from breast cancer, whichever occurred first. Patients without relapse or who were lost to follow-up were censored at the last follow-up. Patients who died as a result of any cause other than breast cancer were censored at the time of death. All statistical analyses were performed using $\mathrm{R}$ version 2.14.0 software [27]. (Last accessed April 29 ${ }^{\text {th }}$, 2013).

For a more in-depth analysis regarding the importance of the proliferation pathway in the behavior of the intrinsic subtypes of breast cancer, we divided each subtype into two groups: with Ki-67 $<14 \%$ or with Ki$67 \geq 14 \%$. The $X^{2}$ test was used to compare the distribution of the baseline characteristics among the subgroups. An actuarial survival was performed using the Kaplan-Meier method, and the differences were assessed with logrank, Tarone-Ware and Peto-Peto tests.
The relationships between the various prognostic factors and BCFS were assessed using a Cox proportional hazard regression. Only cases with information for all covariates were included in this analysis $(n=1,215)$. A variable selection was performed using backward and forward stepwise selection processes (the significance level for entry and permanence of a given variable in the model was $P<0.05)$. Among the different candidate Cox models used to analyze the data, the preferred final model was the one with the minimum Akaike information criterion value [28]. The assumption of hazard proportionality for the model was tested, verifying that the prognostic effect of each covariate was proportional throughout the entire follow-up; that is, the effects did not vary over time. A $P$-value less than 0.05 indicated a violation of the proportional hazards assumption. If the assumption of proportional hazards is rejected, it is necessary to study the changes of recurrence risk rates over time. These hazard functions are estimated from right-censored data using kernel-based methods with a global bandwidth selection algorithm and boundary kernel formulations [29]. Afterward it was confirmed that a smoothed hazard function provided a realistic estimation of the underlying hazard function. The results are presented in accordance with the Reporting Recommendations for Tumor Marker prognostic studies [30].

\section{Results}

\section{Patient cohort}

In the final cohort of 1,249 patients, the median followup was 73.7 months. There were 344 events (27.5\%), of

Table 1 Immunohistochemical definition of breast cancer intrinsic subtypes according to four or six biomarkers ${ }^{\mathrm{a}}$

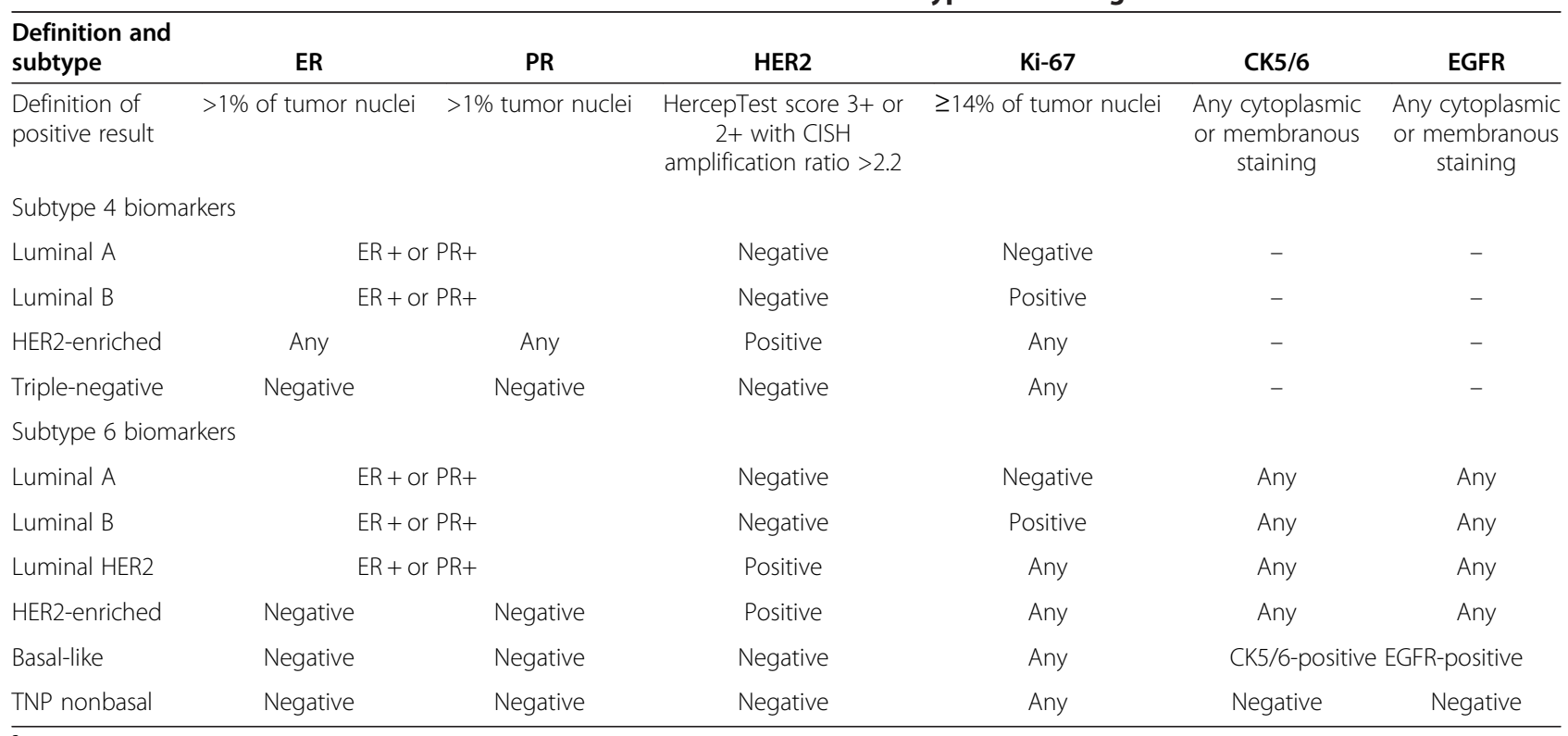

${ }^{a} \mathrm{CISH}$, chromogenic in situ hybridization; CK, cytokeratin; EGFR, epidermal growth factor receptor; ER, estrogen receptor; HER2, human epidermal growth factor receptor 2; PR, progesterone receptor; TNP, triple-negative phenotype. 
which the first event was distant relapse in 272 cases, locoregional recurrence in 64 cases and contralateral tumors in 8 cases.

Clinicopathological characteristics of the patients with intrinsic subtypes defined by the four biomarkers are shown in Table 2 and those defined by the six biomarkers are given in Table 3. The most frequent intrinsic subtype was luminal A (43.2\%), followed by luminal B (30.1\%), triple-negative (14.6\%) and HER2-enriched (12.1\%). Using the six-biomarker definition, there were

Table 2 Patient characteristics for breast cancer intrinsic subtypes defined by four biomarkers ${ }^{a}$

\begin{tabular}{|c|c|c|c|c|c|c|c|c|c|}
\hline \multirow[b]{2}{*}{ Characteristics } & \multicolumn{3}{|c|}{ Luminal $A$ and luminal $B(N=916)$} & \multicolumn{3}{|c|}{ HER2-enriched $(N=151)$} & \multicolumn{3}{|c|}{ Triple-negative $(N=182)$} \\
\hline & $\begin{array}{c}\mathrm{Ki}-67<14 \% \\
(N=540)\end{array}$ & $\begin{array}{c}\mathrm{Ki}-67 \geq 14 \% \\
(N=376)\end{array}$ & $P^{\mathrm{b}}$ & $\begin{array}{c}\mathrm{Ki}-67<14 \% \\
(N=42)^{\mathrm{c}}\end{array}$ & $\begin{array}{c}\mathrm{Ki}-67 \geq 14 \% \\
(N=107)^{\mathrm{c}}\end{array}$ & $P^{\mathrm{b}}$ & $\begin{array}{c}\mathrm{Ki}-67<14 \% \\
(N=38)^{\mathrm{d}}\end{array}$ & $\begin{array}{r}\mathrm{Ki}-67 \geq 14 \% \\
(N=143)^{\mathrm{d}}\end{array}$ & $P^{\mathrm{b}}$ \\
\hline \multicolumn{10}{|l|}{ Age (years), $n(\%)$} \\
\hline$<40$ & $33(6.1)$ & $32(8.5)$ & NS & $4(9.5)$ & $15(14.0)$ & NS & $5(13.2)$ & $22(15.4)$ & NS \\
\hline 40 to 55 & $197(36.5)$ & $139(37.1)$ & & $14(33.3)$ & $49(45.8)$ & & $9(23.7)$ & $58(40.6)$ & \\
\hline$>55$ & $310(57.3)$ & $205(54.4)$ & & $24(57.1)$ & $43(40.2)$ & & $24(63.2)$ & $63(44.1)$ & \\
\hline \multicolumn{10}{|c|}{ Menopausal status, n (\%) } \\
\hline Premenopausal & $172(31.9)$ & $130(34.7)$ & NS & $15(35.7)$ & $53(49.5)$ & NS & $12(31.6)$ & $59(41.3)$ & NS \\
\hline Postmenopausal & $360(66.6)$ & $242(64.3)$ & & $26(61.9)$ & $54(50.5)$ & & $26(68.4)$ & $83(58.0)$ & \\
\hline NA & $8(1.5)$ & $4(1.1)$ & & $1(2.4)$ & - & & - & $1(0.7)$ & \\
\hline \multicolumn{10}{|l|}{ Tumor size (cm), n (\%) } \\
\hline$<2$ & $250(46.4)$ & $158(42.1)$ & NS & $14(33.3)$ & $29(27.1)$ & NS & $8(21.1)$ & $36(25.2)$ & NS \\
\hline 2 to 5 & $261(48.2)$ & $198(52.5)$ & & $23(54.8)$ & $67(62.6)$ & & $27(71.1)$ & $89(62.2)$ & \\
\hline$>5$ & $22(4.1)$ & $14(3.7)$ & & $4(9.5)$ & $10(9.3)$ & & $1(2.6)$ & $13(9.1)$ & \\
\hline NA & $7(1.3)$ & $6(1.6)$ & & $1(2.4)$ & $1(0.9)$ & & $2(5.3)$ & $5(3.5)$ & \\
\hline \multicolumn{10}{|l|}{ Tumor grade, $n(\%)$} \\
\hline 1 & $144(26.7)$ & 39 (10.4) & $<0.0001$ & $2(4.8)$ & $2(1.9)$ & 0.0036 & $1(2.6)$ & $1(0.7)$ & 0.003 \\
\hline 2 & $311(57.5)$ & $226(60.0)$ & & $27(64.3)$ & $43(40.2)$ & & $19(50.0)$ & $38(26.6)$ & \\
\hline 3 & $47(8.7)$ & $91(24.3)$ & & $10(23.8)$ & $55(51.4)$ & & $13(34.2)$ & $90(62.9)$ & \\
\hline NA & $38(7.1)$ & $20(5.3)$ & & $3(7.1)$ & $7(6.5)$ & & $5(13.2)$ & $14(9.8)$ & \\
\hline \multicolumn{10}{|l|}{ Lymph nodes, $n$ (\%) } \\
\hline 0 & $293(54.2)$ & $192(50.9)$ & NS & $15(35.7)$ & $48(44.9)$ & NS & $13(34.2)$ & $77(53.8)$ & NS \\
\hline 1 to 3 & $145(26.9)$ & $109(29.1)$ & & $16(38.1)$ & $28(26.2)$ & & $13(34.2)$ & $36(25.2)$ & \\
\hline$\geq 4$ & $101(18.7)$ & $73(19.5)$ & & $11(26.2)$ & $30(28.0)$ & & $11(28.9)$ & $27(18.9)$ & \\
\hline NA & $1(0.2)$ & $2(0.5)$ & & - & $1(0.9)$ & & $1(2.6)$ & $3(2.1)$ & \\
\hline \multicolumn{10}{|l|}{ Chemotherapy, n (\%) } \\
\hline No & $275(50.8)$ & $174(46.1)$ & NS & $10(23.8)$ & $27(25.2)$ & NS & $9(23.7)$ & $20(14.0)$ & NS \\
\hline Yes & $260(48.2)$ & $199(53.1)$ & & $31(73.8)$ & 79 (73.8) & & $29(76.3)$ & $121(84.6)$ & \\
\hline NA & $5(0.9)$ & $3(0.8)$ & & $1(2.4)$ & $1(0.9)$ & & - & $2(1.4)$ & \\
\hline \multicolumn{10}{|l|}{ Hormonotherapy, n (\%) } \\
\hline No & $106(19.5)$ & $67(17.6)$ & NS & $22(52.4)$ & $45(42.1)$ & NS & $19(50.0)$ & $100(69.9)$ & NS \\
\hline Yes & $432(80.1)$ & $307(81.9)$ & & $20(47.6)$ & $62(57.9)$ & & $19(50.0)$ & $43(30.1)$ & \\
\hline NA & $2(0.4)$ & $2(0.5)$ & & - & - & & - & - & \\
\hline \multicolumn{10}{|l|}{ Local therapy, n (\%) } \\
\hline Mastectomy alone & $172(31.9)$ & $105(28.0)$ & & $19(45.2)$ & $30(28.0)$ & & $20(52.6)$ & $36(25.2)$ & \\
\hline Mastectomy + RT & $61(11.3)$ & $36(9.6)$ & NS & $7(16.7)$ & $16(15.0)$ & NS & $7(18.4)$ & $23(16.1)$ & NS \\
\hline Lumpectomy alone & $28(5.2)$ & $13(3.5)$ & & $1(2.4)$ & $8(7.5)$ & & - & $5(3.5)$ & \\
\hline Lumpectomy + RT & $279(51.6)$ & $222(58.9)$ & & $15(35.7)$ & $53(49.5)$ & & $11(28.9)$ & $79(55.2)$ & \\
\hline
\end{tabular}

${ }^{\mathrm{a}} \mathrm{HER} 2$, human epidermal growth factor receptor 2 ; NA, not available; NS, not significant; RT, radiotherapy. ${ }^{\mathrm{b}} \mathrm{P}$ values were calculated using the $\mathrm{x}^{2}$ test. ${ }^{\mathrm{C}} \mathrm{Two}$ cases with $\mathrm{Ki}-67$ were not available. ${ }^{\mathrm{d}}$ One case with $\mathrm{Ki}-67$ was not available. 
Table 3 Patient characteristics for breast cancer intrinsic subtypes defined by six biomarkers ${ }^{a}$

\begin{tabular}{|c|c|c|c|c|c|c|c|c|c|c|c|c|c|c|c|}
\hline \multirow[b]{2}{*}{ Characteristics } & \multicolumn{3}{|c|}{$\begin{array}{l}\text { Luminal } A \text { and luminal } B \\
\qquad(N=916)\end{array}$} & \multicolumn{3}{|c|}{ Luminal HER2 $(N=77)$} & \multicolumn{3}{|c|}{ HER2-enriched $(N=74)$} & \multicolumn{3}{|c|}{ Basal-like $(N=133)$} & \multicolumn{3}{|c|}{ TNP nonbasal $(N=49)$} \\
\hline & $\begin{array}{c}\mathrm{Ki}-67<14 \% \\
(N=540)\end{array}$ & $\begin{array}{c}\mathrm{Ki}-67 \geq 14 \% \\
(N=376)\end{array}$ & $P^{\mathrm{b}}$ & $\begin{array}{c}\mathrm{Ki}-67<14 \% \\
(N=18)^{\mathrm{c}}\end{array}$ & $\begin{array}{c}\mathrm{Ki}-67 \geq 14 \% \\
(N=57)^{\mathrm{C}}\end{array}$ & $P^{\mathrm{b}}$ & $\begin{array}{c}\mathrm{Ki}-67<14 \% \\
(N=24)\end{array}$ & $\begin{array}{c}\mathrm{Ki}-67 \geq 14 \% \\
(N=50)\end{array}$ & $P^{\mathrm{b}}$ & $\begin{array}{c}\mathrm{Ki}-67<14 \% \\
(N=13)\end{array}$ & $\begin{array}{c}\mathrm{Ki}-67 \geq 14 \% \\
(N=120)\end{array}$ & $P^{\mathrm{b}}$ & $\begin{array}{c}\mathrm{Ki}-67<14 \% \\
(N=25)^{\mathrm{d}}\end{array}$ & $\begin{array}{c}\mathrm{Ki}-67 \geq 14 \% \\
(N=23)^{\mathrm{d}}\end{array}$ & $P^{\mathrm{b}}$ \\
\hline \multicolumn{16}{|l|}{ Age (years), $n(\%)$} \\
\hline$<40$ & $33(6.1)$ & $32(8.5)$ & NS & $2(11.1)$ & $10(17.5)$ & NS & $2(8.3)$ & $5(10.0)$ & NS & $1(7.7)$ & $18(15.0)$ & NS & $4(16.0)$ & $4(17.4)$ & NS \\
\hline 40 to 55 & $197(36.5)$ & $139(37.1)$ & & $5(27.8)$ & $24(42.1)$ & & $9(37.5)$ & $25(50.0)$ & & $3(23.1)$ & $47(39.2)$ & & $6(24.0)$ & $11(47.8)$ & \\
\hline$>55$ & $310(57.3)$ & $205(54.4)$ & & $11(61.1)$ & $23(40.4)$ & & $13(54.2)$ & $20(40.0)$ & & $9(69.2)$ & $55(45.8)$ & & $15(60.0)$ & $8(34.8)$ & \\
\hline \multicolumn{16}{|c|}{ Menopausal status, n (\%) } \\
\hline Premenopausal & $172(31.9)$ & $130(34.7)$ & NS & $6(33.3)$ & $25(43.9)$ & NS & $9(37.5)$ & $28(56.0)$ & NS & $4(30.8)$ & $50(41.7)$ & NS & $8(32.0)$ & $9(39.1)$ & NS \\
\hline Postmenopausal & $360(66.6)$ & $242(64.3)$ & & $11(61.1)$ & $32(56.1)$ & & $15(62.5)$ & $22(44.0)$ & & $9(69.2)$ & $70(58.3)$ & & $17(68.0)$ & $13(56.5)$ & \\
\hline NA & $8(1.5)$ & $4(1.1)$ & & $1(5.6)$ & - & & - & - & & - & - & & - & $1(4.3)$ & \\
\hline \multicolumn{16}{|c|}{ Tumor size (cm), n (\%) } \\
\hline$<2$ & $250(46.4)$ & $158(42.1)$ & NS & $8(44.2)$ & $18(31.6)$ & NS & $6(25.0)$ & $11(22.0)$ & NS & $2(15.4)$ & $30(25)$ & NS & $6(24.0)$ & $6(26.1)$ & NS \\
\hline 2 to 5 & $261(48.2)$ & $198(52.5)$ & & $9(50.0)$ & $36(63.2)$ & & $14(58.3)$ & $31(62.0)$ & & $10(76.9)$ & $77(64.2)$ & & $17(68.0)$ & $12(52.2)$ & \\
\hline$>5$ & $22(4.1)$ & $14(3.7)$ & & - & $3(5.3)$ & & $45(16.7)$ & $7(14.0)$ & & - & $8(6.7)$ & & $1(4.0)$ & $5(21.7)$ & \\
\hline NA & $7(1.3)$ & $6(1.6)$ & & $1(5.6)$ & - & & - & $1(2.0)$ & & $1(7.7)$ & $5(4.2)$ & & $1(4.0)$ & - & \\
\hline \multicolumn{16}{|l|}{ Tumor grade, $n(\%)$} \\
\hline 1 & $144(26.7)$ & $39(10.4)$ & $<.0001$ & $1(5.9)$ & $2(3.8)$ & .004 & $1(4.2)$ & - & NS & - & $1(0.8)$ & NS & $1(4.0)$ & - & .005 \\
\hline 2 & $311(57.5)$ & $226(60.0)$ & & $15(88.2)$ & $26(50.0)$ & & $12(50.0)$ & $17(34.0)$ & & $4(30.8)$ & $32(26.7)$ & & $15(60.0)$ & $6(26.1)$ & \\
\hline 3 & $47(8.7)$ & $91(24.3)$ & & $1(5.9)$ & $24(46.2)$ & & $9(37.5)$ & $31(62.0)$ & & $8(61.5)$ & $75(625)$ & & $5(20.0)$ & $15(65.2)$ & \\
\hline NA & $38(7.1)$ & $20(5.3)$ & & - & - & & $2(8.3)$ & $2(4.0)$ & & $1(7.7)$ & $12(10.0)$ & & $4(16.0)$ & $2(8.7)$ & \\
\hline \multicolumn{16}{|l|}{ Lymph nodes, $n$ (\%) } \\
\hline 0 & $293(54.2)$ & $192(50.9)$ & NS & $9(50.0)$ & $31(54.4)$ & NS & $6(25.0)$ & $17(34.0)$ & NS & $3(23.1)$ & $64(53.3)$ & NS & $10(40.0)$ & $13(56.5)$ & NS \\
\hline 1 to 3 & $145(26.9)$ & $109(29.1)$ & & $7(38.9)$ & 18 (31.6) & & $9(37.5)$ & $10(20.0)$ & & $5(38.5)$ & $32(26.7)$ & & $8(32.0)$ & $4(17.4)$ & \\
\hline$\geq 4$ & $101(18.7)$ & $73(19.5)$ & & $2(11.1)$ & $8(14.0)$ & & $9(37.5)$ & $22(44.0)$ & & $5(38.5)$ & $23(19.2)$ & & $6(24.0)$ & $4(17.4)$ & \\
\hline NA & $1(0.2)$ & $2(0.5)$ & & - & - & & - & $1(2.0)$ & & - & - & & $1(4.0)$ & $2(8.7)$ & \\
\hline \multicolumn{16}{|l|}{ Chemotherapy, n (\%) } \\
\hline No & $275(50.8)$ & $174(46.1)$ & NS & $8(44.4)$ & $16(28.1)$ & NS & $2(8.3)$ & $11(22.0)$ & NS & $2(15.4)$ & $16(13.3)$ & NS & $7(28.0)$ & $7(17.4)$ & NS \\
\hline Yes & $260(48.2)$ & $199(53.1)$ & & $10(55.6)$ & $41(71.9)$ & & $21(87.5)$ & $38(76.0)$ & & $11(84.6)$ & $102(85.0)$ & & $18(72.0)$ & 19 (82.6) & \\
\hline NA & $5(0.9)$ & $3(0.8)$ & & - & - & & $1(4.2)$ & $1(2.0)$ & & - & $2(1.7)$ & & - & - & \\
\hline
\end{tabular}


Table 3 Patient characteristics for breast cancer intrinsic subtypes defined by six biomarkers ${ }^{\mathrm{a}}$ (Continued)

\begin{tabular}{|c|c|c|c|c|c|c|c|c|c|c|c|c|c|c|c|}
\hline \multicolumn{16}{|c|}{ Hormonotherapy, n (\%) } \\
\hline No & $106(19.5)$ & 67 (17.6) & NS & $4(22.2)$ & $13(22.8)$ & NS & $18(75.0)$ & $32(64.0)$ & NS & $9(69.2)$ & $86(71.7)$ & NS & $10(40)$ & $14(60.9)$ & \\
\hline Yes & $432(80.1)$ & 307 (81.9) & & $14(77.8)$ & $44(77.2)$ & & $6(25.0)$ & $18(36.0)$ & & $4(30.8)$ & $34(28.3)$ & & $15(60)$ & $9(39.1)$ & \\
\hline NA & $2(0.4)$ & $2(0.5)$ & & - & - & & - & - & & - & - & & - & - & \\
\hline \multicolumn{16}{|l|}{ Local therapy, n (\%) } \\
\hline $\begin{array}{l}\text { Mastectomy } \\
\text { alone }\end{array}$ & $172(31.9)$ & $105(28.0)$ & & $7(38.9)$ & $14(24.6)$ & & $12(50.0)$ & $16(32.0)$ & & $5(38.5)$ & $28(23.3)$ & & $15(60.0)$ & $8(34.8)$ & \\
\hline Mastectomy + RT & $61(11.3)$ & $36(9.6)$ & NS & $1(5.6)$ & $5(8.8)$ & NS & $6(25.0)$ & $11(22.0)$ & NS & $3(23.1)$ & $17(14.2)$ & NS & $4(16.0)$ & $6(26.1)$ & NS \\
\hline $\begin{array}{l}\text { Lumpectomy } \\
\text { alone }\end{array}$ & $28(5.2)$ & $13(3.5)$ & & $1(5.6)$ & $4(7.0)$ & & - & $4(8.0)$ & & - & $5(4.2)$ & & - & - & \\
\hline $\begin{array}{l}\text { Lumpectomy + } \\
\text { RT }\end{array}$ & $279(51.6)$ & $222(58.9)$ & & $9(50.0)$ & $34(59.6)$ & & $6(25.0)$ & $19(38.0)$ & & $5(38.5)$ & $70(58.3)$ & & $6(24.0)$ & $9(39.1)$ & \\
\hline
\end{tabular}

${ }^{a} \mathrm{HER} 2$, human epidermal growth factor receptor 2 ; NA, not available; NS, not significant; RT, radiotherapy. ${ }^{\mathrm{b}} \mathrm{P}$ values were calculated using the $\mathrm{x}^{2}$ test. ${ }^{\mathrm{C}} \mathrm{Two}$ cases with Ki-67 NA. ${ }^{\mathrm{d}} \mathrm{One}$ case with Ki-67 NA. 
6.2\% luminal HER2 cases, 5.9\% HER2-enriched cases, 10.7\% basal-like cases and 3.9\% TNP nonbasal cases.

Among patients with the various intrinsic subtypes, there were significant differences in histological grade depending on the proliferation rate defined by the Ki-67 index (Tables 2 and 3).

\section{Analysis of actuarial breast cancer-free survival by intrinsic subtype and proliferation rate}

The molecular subtypes differed significantly in BCFS when the four-biomarker definition was used (Figure 2A), with luminal A cases exhibiting the longest survival $(P=0.001)$. Analysis of BCFS in each intrinsic subtype according to Ki-67 value revealed a significant difference in the luminal subtypes (odds ratio $(\mathrm{OR})=0.71$, 95\% CI $=0.39$ to $0.93 ; P=0.009$ (luminal A vs. luminal $\mathrm{B}$ )) (Figure 2B), but not in the HER2-enriched subtype (OR = $0.63,95 \% \mathrm{CI}=0.24$ to $1.65 ; P=0.1$ ) (Figure $2 \mathrm{C}$ ) or the triple-negative subtype $(\mathrm{OR}=0.96,95 \% \mathrm{CI}=0.42$ to 2.33 ; $P=0.9$ ) (Figure 2D). Similar results were obtained when the six-immunomarker definition was used (Figure 3).
In Table 4, the cumulative 3-year and 5-year BCFS rates for the four intrinsic subtypes are listed. At 3 years, the absolute difference in BCFS between the luminal A and the luminal B phenotypes was $7.6 \%$, which is comparable to the difference found at 5 years (8.7\%). Similar data were found regarding the luminal A and the HER2enriched phenotypes ( $19.5 \%$ and $17.1 \%$, respectively) and the luminal A and triple-negative phenotypes (18.3\% and $17.4 \%$, respectively). The results exhibited similar trends when the six-marker definition was used (Table 5).

\section{Analysis of recurrence prognostic factors and variations in recurrence risk over time}

The final model for multivariate analyses of BCFS for patients classified using the four biomarkers revealed that tumor size, lymph node status, type of local therapy, use of adjuvant endocrine therapy and intrinsic subtypes were significant independent predictors of disease recurrence (Table 6). The analysis of compliance with proportional hazards assumptions were rejected $(P<0.0001)$, indicating that recurrence risks were not proportional

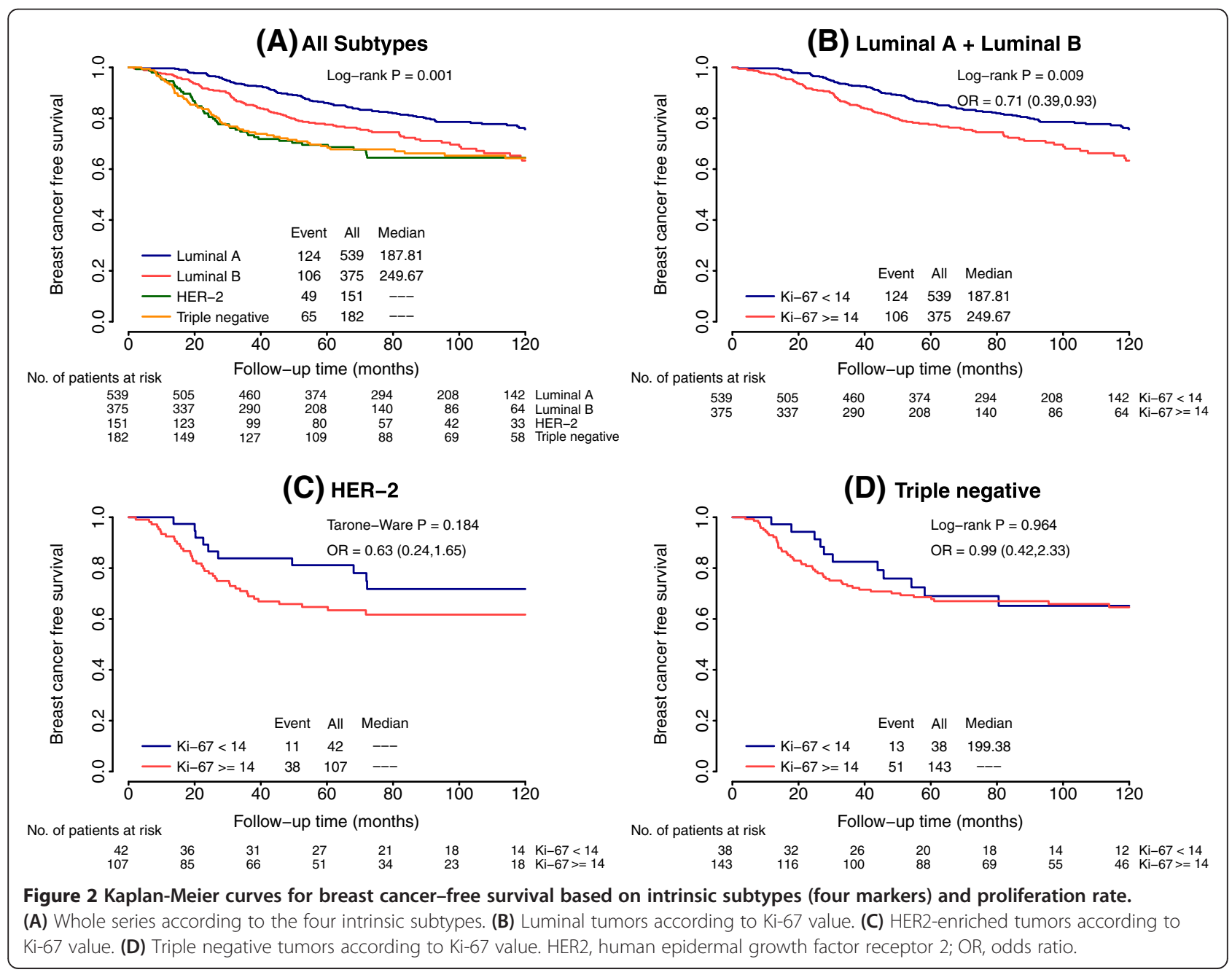


(A) All Subtypes

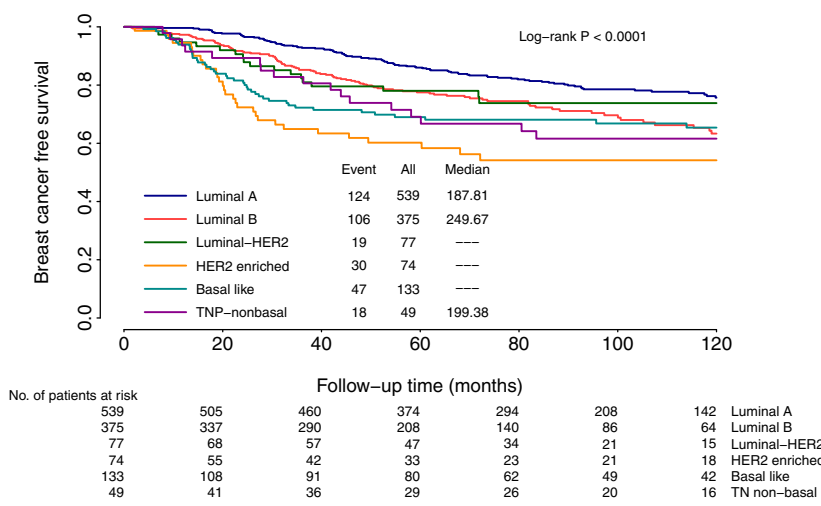

(C) Luminal-HER2T

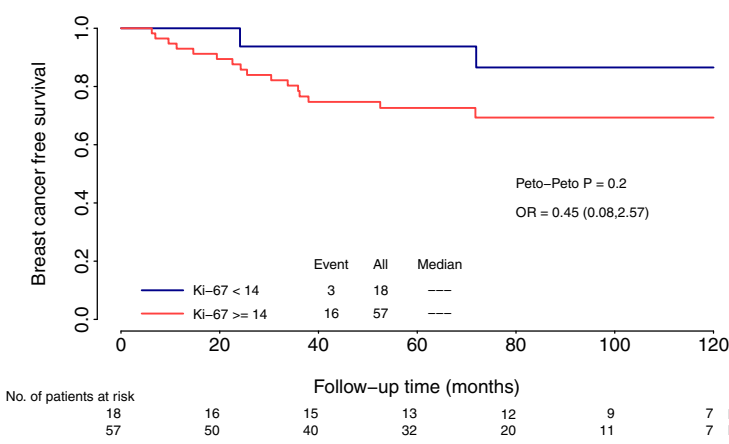

(E) TNP non-basal

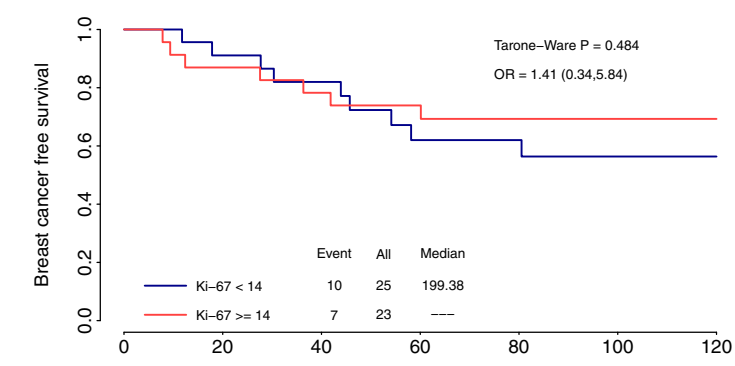

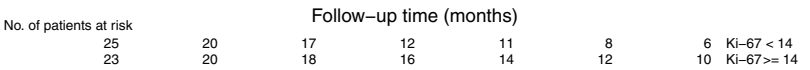

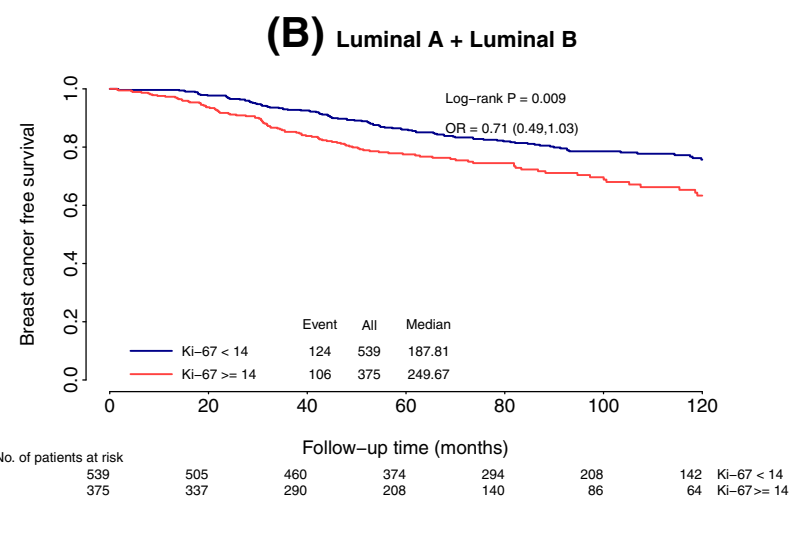

(D) HER2 enriched

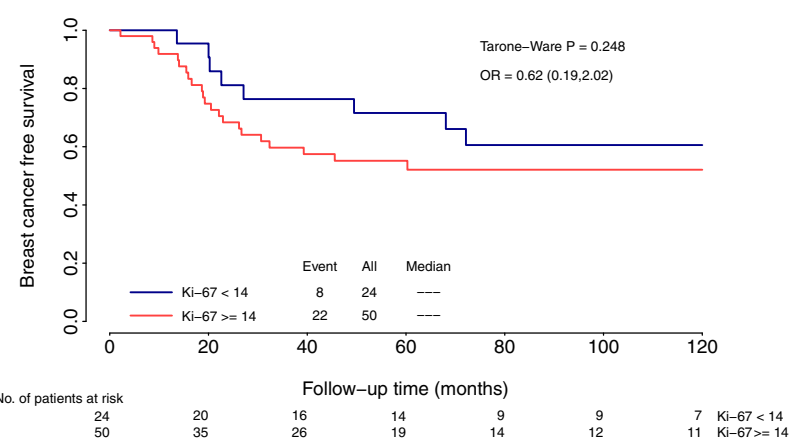

(F) Basal like

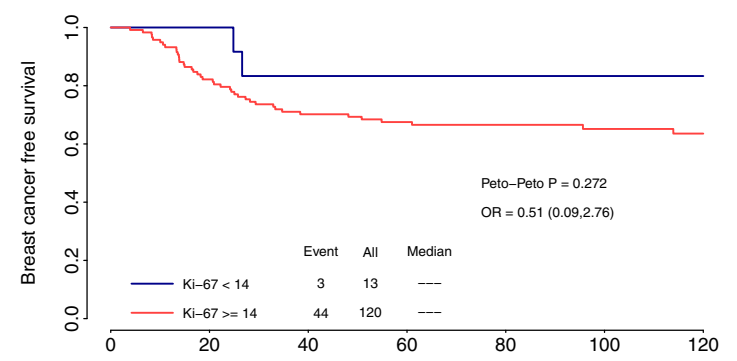

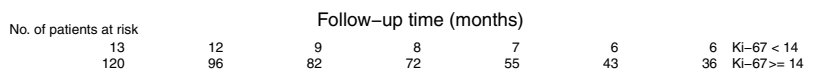

Figure 3 Kaplan-Meier curves for breast cancer-free survival based on intrinsic subtypes (six markers) and proliferation rate. (A) Whole series according to six intrinsic subtypes. TNP, triple-negative phenotype. (B) Luminal tumors according to Ki-67 value. OR, odds ratio. (C) Luminal human epidermal growth factor receptor 2 (HER2) tumors according to Ki-67 value. (D) HER2-enriched tumors according to Ki-67 value. (E) Triplenegative-nonbasal tumors according to Ki-67 value. (F) Basal-like tumors according to Ki-67 value.

Table 4 Estimated cumulative breast cancer-free survival (four-marker definition) ${ }^{\mathrm{a}}$

\begin{tabular}{lcccccc}
\hline Intrinsic subtype & 2-year BCFS & 95\% Cl & 3-year BCFS & 95\% Cl & 5-year BCFS & 95\% Cl \\
\hline Luminal A & $96.7 \%$ & $95.2 \%$ to $98.3 \%$ & $92.8 \%$ & $90.6 \%$ to $95.0 \%$ & $85.8 \%$ & $82.7 \%$ to $88.9 \%$ \\
Luminal B & $91.5 \%$ & $88.6 \%$ to $94.4 \%$ & $85.2 \%$ & $81.6 \%$ to $89.0 \%$ & $77.1 \%$ & $72.8 \%$ to $81.7 \%$ \\
HER2-enriched & $81.2 \%$ & $75.0 \%$ to $87.8 \%$ & $73.3 \%$ & $66.4 \%$ to $81.0 \%$ & $68.7 \%$ & $61.4 \%$ to $76.8 \%$ \\
Triple-negative & $83.0 \%$ & $77.7 \%$ to $88.8 \%$ & $74.5 \%$ & $68.3 \%$ to $81.2 \%$ & $\mathbf{6 8 . 4 \%}$ & $61.8 \%$ to $75.7 \%$ \\
\hline
\end{tabular}

${ }^{\mathrm{a}} \mathrm{BCFS}$, breast cancer-free survival; $\mathrm{Cl}$, confidence interval; HER2, human epidermal growth factor 2. All values are statistically significant. 
Table 5 Estimated cumulative breast cancer-free survival (six-marker definition) ${ }^{\text {a }}$

\begin{tabular}{lcccccc}
\hline Intrinsic subtype & 2-year BCFS & 95\% Cl & 3-year BCFS & 95\% Cl & 5-year BCFS & 95\% Cl \\
\hline Luminal A & $96.7 \%$ & $95.2 \%$ to $98.3 \%$ & $92.8 \%$ & $90.6 \%$ to $95.0 \%$ & $85.8 \%$ & $82.7 \%$ to $88.9 \%$ \\
Luminal B & $91.5 \%$ & $88.6 \%$ to $94.4 \%$ & $85.2 \%$ & $81.6 \%$ to $89.0 \%$ & $77.1 \%$ & $72.8 \%$ to $81.7 \%$ \\
Luminal HER2 & $89.2 \%$ & $82.5 \%$ to $96.6 \%$ & $81.0 \%$ & $72.4 \%$ to $90.5 \%$ & $77.1 \%$ & $68.8 \%$ to $72.4 \%$ \\
HER2-enriched & $72.4 \%$ & $62.5 \%$ to $83.8 \%$ & $63.9 \%$ & $53.5 \%$ to $76.3 \%$ & $58.3 \%$ & $47.6 \%$ to $71.5 \%$ \\
Basal-like & $80.8 \%$ & $74.3 \%$ to $87.9 \%$ & $72.2 \%$ & $64.9 \%$ to $80.4 \%$ & $68.1 \%$ & $60.5 \%$ to $76.7 \%$ \\
TNP nonbasal & $89.3 \%$ & $80.9 \%$ to $98.6 \%$ & $80.6 \%$ & $70.0 \%$ to $92.8 \%$ & $66.7 \%$ & $54.2 \%$ to $82.1 \%$ \\
\hline
\end{tabular}

${ }_{\mathrm{a}}^{\mathrm{B} C F S}$, breast cancer-free survival; $\mathrm{Cl}$, confidence interval; HER2, human epidermal growth factor 2; TNP, triple-negative phenotype. All values are statistically significant.

over time. To further explore this issue, an analysis of the hazards function according to the intrinsic subtypes was performed, and the resulting smoothed curves are shown in Figure 4. We also investigated whether these patterns of relapse differed regarding the proliferation rate. The luminal A cases, with Ki-67 $<14 \%$, had a progressive increased risk that approached $0.3 \%(95 \% \mathrm{CI}=$ $0.2 \%$ to $0.4 \%$ ) at 39.4 months, with the curve remaining nearly steady during the rest of follow-up (Figure 4B). However, luminal B patients, with Ki-67 $\geq 14 \%$, displayed a different pattern of recurrence. A maximum risk of $0.5 \%$ ( $95 \% \mathrm{CI}=0.4 \%$ to $0.6 \%)$ was reached at 33.8 months, and a second peak of late recurrence risk $(0.3 \% ; 95 \% \mathrm{CI}=0.2 \%$ to $0.5 \%$ ) appeared at 112 months (Figure 4B). For the HER2-enriched subtype, the first peak occurred at approximately the same time, nearly 20 months for both groups, but the maximum risk was $1.0 \%(95 \% \mathrm{CI}=0.5 \%$ to $2 \%$ ) in patients with $\mathrm{Ki}-67<14 \%$ and a maximum risk of $1.3 \%$ (95\% CI $=0.9 \%$ to $3.1 \%$ ) in those cases with Ki-67 $\geq 14 \%$. A second risk peak at 72 months appeared for both HER2 populations, but, interestingly, the magnitude in this case seems to be higher in the HER2enriched group with $\mathrm{Ki}-67<14 \%(0.75 \%$ risk; $95 \% \mathrm{CI}=$ $0.3 \%$ to $1.8 \%)$ than with $\mathrm{Ki}-67 \geq 14 \%$ (0.25\% risk; $95 \%$ $\mathrm{CI}=0.08 \%$ to $2.7 \%$ ) (Figure $4 \mathrm{C}$ ). Triple-negative cases with low Ki-67 exhibited a smooth curve. After a maximum risk of $0.7 \%$ (95\% CI: $0.4 \%$ to $1.7 \%$ ) reached at 32.6 months, the curve remained nearly steady until 52 months, at which point it started to decline. The maximum recurrence risk for triple-negative and high Ki-67 patients was reached at 17.7 months $(0.9 \%$ risk; $95 \% \mathrm{CI}=0.6 \%$ to $1.1 \%$ ), decreased to $0.3 \%$ by 48 months ( $95 \% \mathrm{CI}=0.2 \%$ to $0.5 \%$ ) and was minimal at 80 months (0.04\% risk; $95 \% \mathrm{CI}=0.007 \%$ to $0.2 \%$ ) (Figure $4 \mathrm{D}$ ).

The recurrence hazard rates for the intrinsic subtypes at different time points are listed in Table 7, showing their respective hazard ratios and considering luminal A as the reference value. It is noteworthy that the information is quite different from data derived from actuarial BCFS, in which the absolute differences between each intrinsic subtype and luminal A were comparable at two time points: 36 and 60 months. The initial risk for luminal $\mathrm{B}$ is about twice that for luminal $\mathrm{A}$, and, after
36 months, this risk decreases slowly. After the eighth year, however, the recurrence risk for luminal $\mathrm{B}$ increases to more than twice that of luminal A. For HER2enriched patients, the risk is nearly fivefold that of luminal A during the first 2 years and double at 36 months. Between the fourth and the fifth years after surgery, however, the recurrence risk for HER2-enriched patients is lower than that for luminal A patients. After that time, the recurrence risk for HER2-enriched patients increases, becoming more than twice that of luminal A. The risk of recurrence for triple-negative tumors is three

Table 6 Final multivariate Cox analysis of breast cancerfree survival with four-biomarker definition of intrinsic subtypes $^{a}$

\begin{tabular}{|c|c|c|c|}
\hline Variables & HR & $95 \% \mathrm{Cl}$ & $P^{\mathrm{b}}$ \\
\hline \multicolumn{4}{|l|}{ Tumor size, cm } \\
\hline$<2$ & 1.0 & & \\
\hline 2 to 5 & 1.6 & 1.2 to 2.1 & 0.0004 \\
\hline$>5$ & 1.9 & 1.2 to 3.1 & 0.005 \\
\hline \multicolumn{4}{|l|}{ Lymph nodes } \\
\hline 0 & 1.0 & & \\
\hline 1 to 3 & 1.4 & 1.0 to 1.8 & 0.01 \\
\hline$\geq 4$ & 2.8 & 2.1 to 3.7 & $<0.0001$ \\
\hline \multicolumn{4}{|l|}{ Local therapy } \\
\hline Mastectomy alone & 1.0 & & \\
\hline Mastectomy + RT & 1.1 & 0.7 to 1.5 & 0.6 \\
\hline Lumpectomy alone & 1.2 & 0.6 to 2.1 & 0.5 \\
\hline Lumpectomy + RT & 0.6 & 0.4 to 0.8 & 0.0005 \\
\hline \multicolumn{4}{|l|}{ Endocrine therapy } \\
\hline Yes & 1.0 & & \\
\hline No & 0.7 & 0.5 to 0.9 & 0.01 \\
\hline \multicolumn{4}{|l|}{ Subtype } \\
\hline Luminal A & 1.0 & & \\
\hline Luminal B & 1.3 & 1.0 to 1.7 & 0.02 \\
\hline HER2-enriched & 1.4 & 1.0 to 2.0 & 0.04 \\
\hline Triple-negative & 1.3 & 0.9 to 1.8 & 0.09 \\
\hline
\end{tabular}

${ }^{\mathrm{a}} \mathrm{Cl}$, confidence interval; HER2, human epidermal growth factor receptor 2; HR, hazard ratio; RT, radiotherapy. ${ }^{\mathrm{b}} \mathrm{All}$ likelihood ratio, Wald and logrank statistical tests were two-sided. 


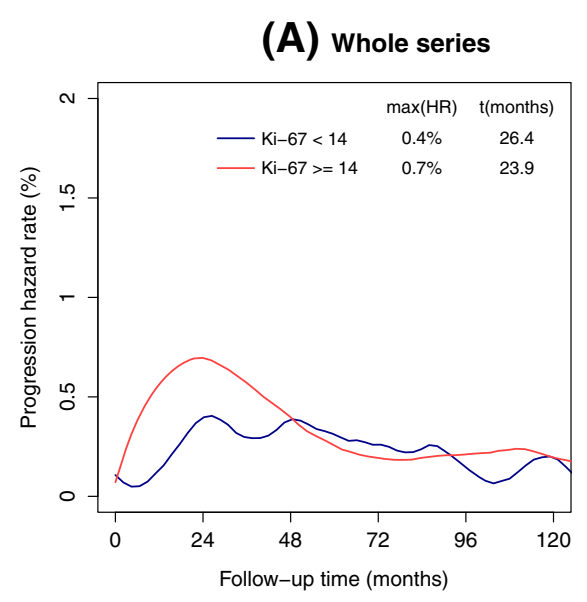

(C) HER-2

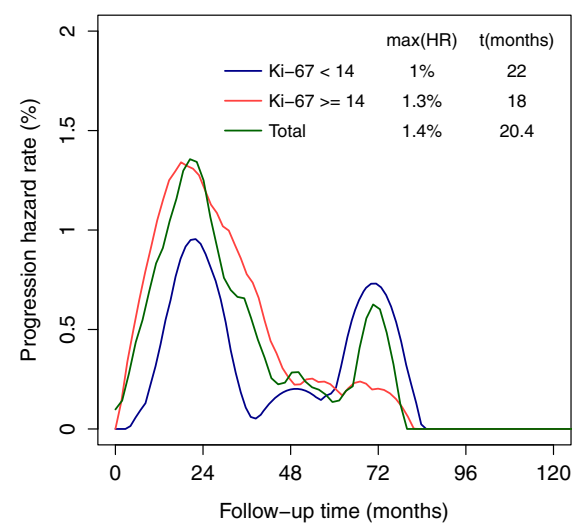

(B) Luminal

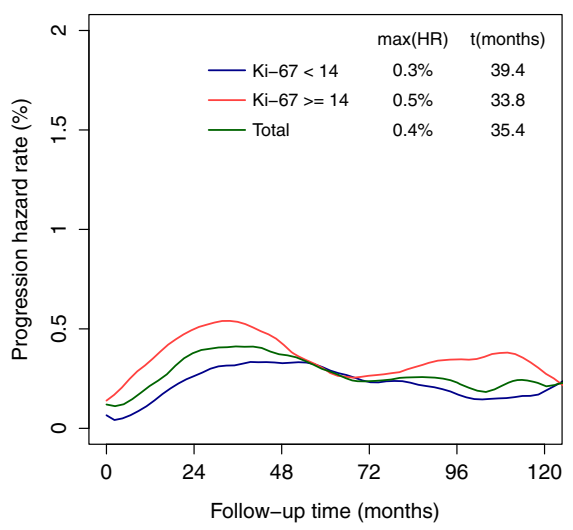

(D) Triple Negative

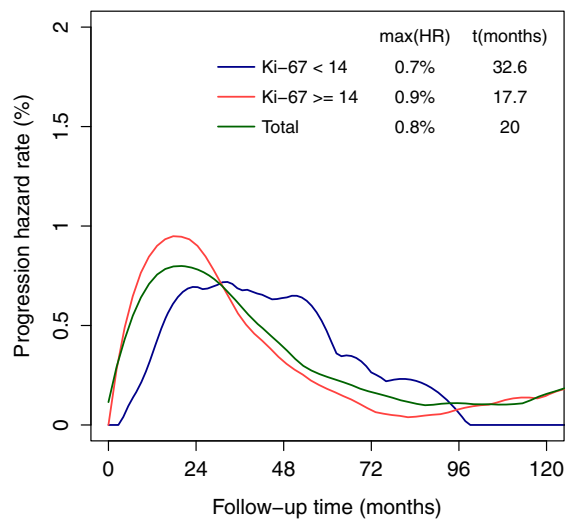

Figure 4 Recurrence hazard rate functions for intrinsic subtypes (four markers) and proliferation rate. (A) Whole series according to Ki-67 value. (B) Luminal tumors as a whole and according to Ki-67 value. (C) Human epidermal growth factor 2 (HER2)-enriched tumors as a whole and according to Ki-67 value. (D) Triple-negative tumors as a whole and according to Ki-67 value. max(HR), maximum hazard rate.

times higher than that for luminal A during the first 2 years and nearly double at 36 months; however, at 60 months, the recurrence risk is similar between the two subtypes.

Similar results were obtained when multivariate analysis was performed with intrinsic subgroup populations defined by the six biomarkers (Table 8). In the same way, each intrinsic subtype displayed a specific pattern of recurrence over time, although the analysis based on the Ki-67 value was not performed, owing to the size of the subgroups, which were too small to make estimates realistic (Figure 5 and Table 9).

\section{Discussion}

Our work highlights the importance of the proliferation pathway in the prognosis of early breast cancer intrinsic subtypes through the analysis of patient outcomes in different and complementary ways.

On the basis of genomics-defined luminal tumors, it has been possible to establish a value of Ki-67 with prognostic utility usefulness in distinguishing luminal tumors A and B [12]. Moreover, several studies have confirmed the prognostic usefulness of these intrinsic subtypes defined by four immunohistochemical markers [6-10] or six immunohistochemical markers [8,13-15]. However, the value of $\mathrm{Ki}-67$ as a prognostic marker in the other intrinsic subtypes, such as triple-negative and HER2-enriched, is not clear. In our study, only the luminal population demonstrated significant differences in actuarial BCFS according to Ki-67 value. No significant differences were found in triple-negative and HER2enriched tumors. It is possible that these findings are based on our use of a Ki-67 cutoff obtained in luminal tumors. Nevertheless, Aleskandarany et al. also failed to detect a significant difference in actuarial survival, despite using different cutoffs defined specifically for both triple-negative and HER2-enriched tumors [31].

To improve the results obtained using adjuvant therapy in breast cancer, it is important to develop methods for accurately determining which patients need some 
Table 7 Intrinsic subtypes' recurrence hazard rates over time and hazard ratios (Four markers definition) ${ }^{\text {a }}$

\begin{tabular}{|c|c|c|c|c|c|c|c|c|}
\hline $\begin{array}{l}\text { Years after } \\
\text { surgery }\end{array}$ & $\begin{array}{c}\text { Luminal A hazard } \\
\text { rate }^{\mathbf{b}}\end{array}$ & $\mathrm{HR}$ & $\begin{array}{l}\text { Luminal } B \text { hazard } \\
\text { rate }\end{array}$ & HR & $\begin{array}{l}\text { HER2-enriched hazard } \\
\text { rate }\end{array}$ & HR & $\begin{array}{l}\text { Triple-negative hazard } \\
\text { rate }\end{array}$ & $\mathrm{HR}$ \\
\hline 2 & $0.26(0.2$ to 0.3$)$ & 1 & 0.50 (0.4 to 0.6$)$ & 1.9 & 1.26 (0.8 to 2.0$)$ & 4.8 & 0.78 (0.6 to 1.0$)$ & 3.0 \\
\hline 3 & $0.32(0.2$ to 0.4$)$ & 1 & $0.54(0.4$ to 0.6$)$ & 1.7 & 0.63 (0.3 to 1.3$)$ & 2.0 & 0.60 (0.4 to 0.8$)$ & 1.9 \\
\hline 4 & $0.33(0.2$ to 0.4$)$ & 1 & 0.43 (0.3 to 0.5$)$ & 1.3 & 0.28 (0.1 to 0.9$)$ & 0.8 & 0.39 (0.2 to 0.5$)$ & 1.2 \\
\hline 5 & 0.30 (0.2 to .04$)$ & 1 & 0.29 (0.2 to 0.4$)$ & 1.0 & $0.14(.02$ to 1.0$)$ & 0.4 & 0.24 (0.1 to 0.4$)$ & 0.8 \\
\hline 6 & 0.23 (0.1 to 0.3$)$ & 1 & $0.26(0.2$ to 0.5$)$ & 1.1 & 0.62 (0.2 to 1.7$)$ & 2.6 & 0.17 (.06 to 0.3$)$ & 0.7 \\
\hline 7 & 0.23 (0.1 to 0.3$)$ & 1 & 0.31 (0.2 to 0.6$)$ & 1.4 & NA & NA & 0.11 (.04 to 0.3$)$ & 0.5 \\
\hline 8 & 0.17 (0.1 to 0.2$)$ & 1 & 0.35 (0.2 to 0.7 ) & 2.0 & NA & NA & 0.11 (.04 to 0.3$)$ & 0.6 \\
\hline 9 & 0.15 (0.1 to 0.3$)$ & 1 & 0.38 (0.2 to 0.7$)$ & 2.5 & NA & NA & 0.10 (.03 to 0.3$)$ & 0.7 \\
\hline 10 & 0.19 (0.1 to 0.4$)$ & 1 & 0.28 (0.1 to 0.6$)$ & 1.5 & NA & NA & $0.16(.06$ to 0.4$)$ & 0.8 \\
\hline
\end{tabular}

${ }^{\mathrm{a}} \mathrm{HR}$, hazard ratio; HER2, human epidermal growth factor receptor 2; NA, not available. ${ }^{\mathrm{b}}$ Reference value. Note: $95 \%$ confidence intervals are presented in parentheses.

kind of treatment. Furthermore, it is necessary to establish the best treatment option for each patient and the best timing of treatment administration, because previous studies have shown that there are significant differences in the timing of disease recurrence, depending on tumor characteristics. Using a cumulative survival methodology, researchers in various studies have found that, in triple-negative and HER2 phenotypes, most relapses occur during the first 3 years of follow-up, whereas in the luminal subtypes, a significant number of recurrences occur in subsequent years [32-38]. Nevertheless, the use of the hazard function analysis methodology defines, in much greater detail, the changes in the risk of relapse over time, highlighting when a recurrence occurs rather than simply calculating the overall recurrence risk. In our Kaplan-Meier data, there were no appreciable absolute differences in 3-year and 5-year BCFS between luminal A and luminal B cases $(7.6 \%$ and $8.7 \%$, respectively), luminal A and HER2-enriched cases (19.5\% and $17.1 \%$, respectively) or luminal $\mathrm{A}$ and triple-negative cases $(18.3 \%$ and $17.4 \%$, respectively). However, the hazard function analysis detected noteworthy differences in the relapse risk between these subgroups at the same time points. Luminal B patients had about twice the recurrence risk of luminal A patients 3 years after surgery, whereas the hazard ratio was only 1.0 at 5 years. In HER2-enriched tumors, the recurrence hazard ratio in comparison with luminal A was 2.0 at 3 years and 0.4 at 5 years postsurgery. Also, triple-negative patients had different recurrence risks when luminal A data were considered as reference values (1.9 at 3 years and 0.8 at 5 years).

A visual inspection of the recurrence hazard curves presented herein shows that each intrinsic subtype has a particular pattern of relapse over time. More importantly, these patterns change depending on the level of activation of the proliferation pathway as determined by Ki-67. To date, few studies have examined the temporal
Table 8 Final multivariate Cox analysis of breast cancerfree survival with six-biomarker definition of intrinsic subtypes $^{\mathrm{a}}$

\begin{tabular}{|c|c|c|c|}
\hline Variable & HR & $95 \% \mathrm{Cl}$ & $P^{\mathbf{b}}$ \\
\hline \multicolumn{4}{|l|}{ Tumor size, cm } \\
\hline$<2$ & 1.0 & & \\
\hline 2 to 5 & 1.6 & 1.2 to 2.1 & 0.0003 \\
\hline$>5$ & 2.0 & 1.2 to 3.2 & 0.005 \\
\hline \multicolumn{4}{|l|}{ Lymph nodes } \\
\hline 0 & 1.0 & & \\
\hline 1 to 3 & 1.4 & 1.0 to 1.8 & 0.01 \\
\hline$\geq 4$ & 2.8 & 2.1 to 3.7 & $<0.0001$ \\
\hline \multicolumn{4}{|l|}{ Local therapy } \\
\hline Mastectomy alone & 1.0 & & \\
\hline Mastectomy + RT & 1.1 & 0.8 to 1.5 & 0.6 \\
\hline Lumpectomy alone & 1.2 & 0.7 to 2.1 & 0.5 \\
\hline Lumpectomy + RT & 0.6 & 0.5 to 0.8 & 0.0009 \\
\hline \multicolumn{4}{|l|}{ Hormonotherapy } \\
\hline Yes & 1.0 & & \\
\hline No & 0.7 & 0.5 to 0.9 & 0.01 \\
\hline \multicolumn{4}{|l|}{ Subtype } \\
\hline Luminal A & 1.0 & & \\
\hline Luminal B & 1.4 & 1.1 to 1.7 & 0.02 \\
\hline Luminal HER2 & 1.4 & 0.8 to 2.2 & 0.2 \\
\hline HER2-enriched & 1.5 & 0.9 to 2.2 & 0.08 \\
\hline Basal-like & 1.2 & 0.8 to 1.8 & 0.3 \\
\hline TNP nonbasal & 1.6 & 0.9 to 2.6 & 0.06 \\
\hline
\end{tabular}

${ }^{\mathrm{a}} \mathrm{Cl}$, confidence interval; $\mathrm{HR}$, hazard ratio; HER2, human epidermal growth factor receptor 2; RT, radiotherapy; TNP, triple-negative phenotype. ${ }^{\mathrm{b}}$ All likelihood ratio, Wald and logrank statistical tests were two-sided. 


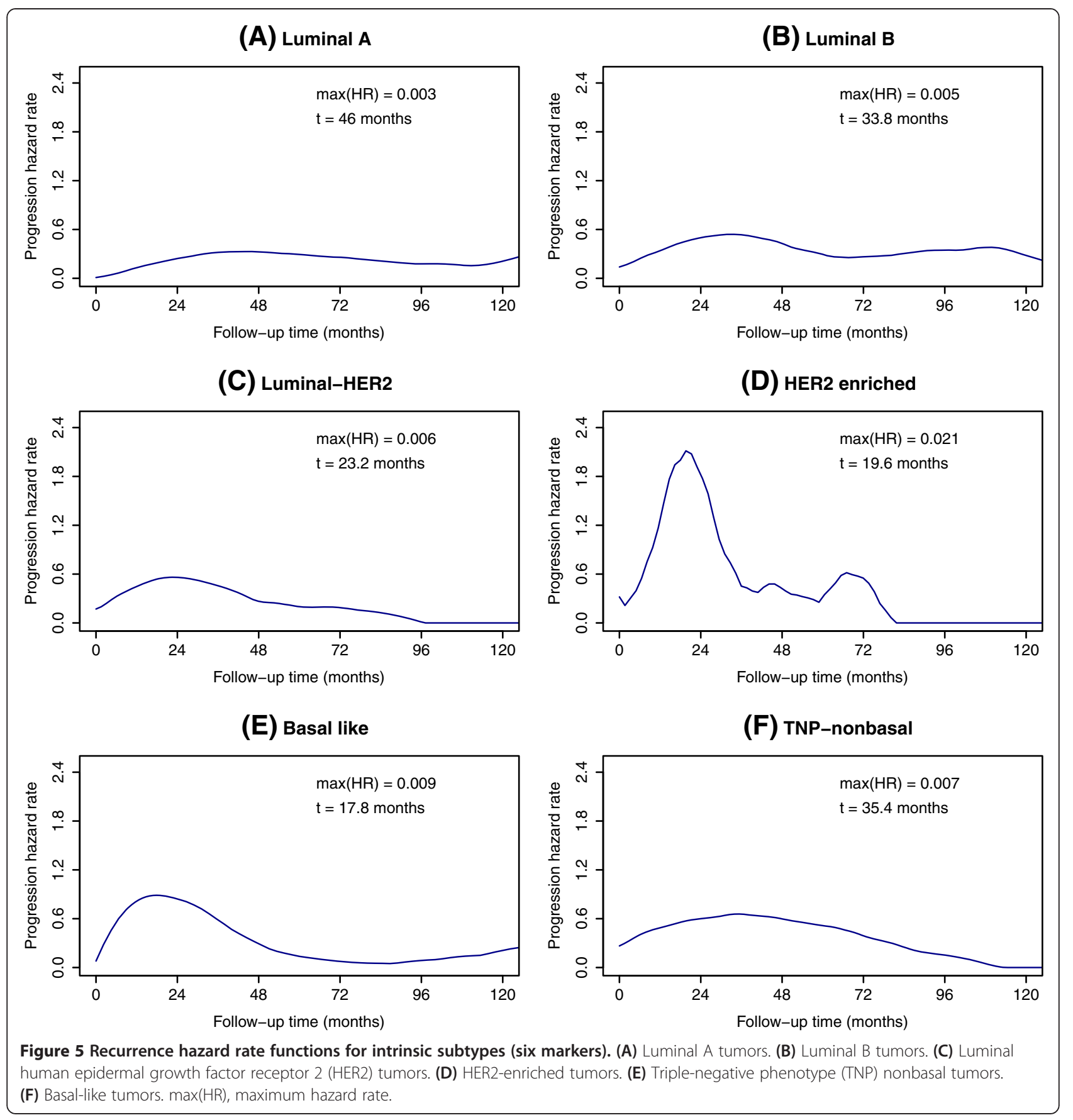

pattern of recurrence in the various intrinsic subtypes, and the results of these studies have demonstrated hazard function curves similar to ours. Greater short-term risk between 1 and 3 years after surgery was observed in the triple-negative tumors [34,38-42], HER2-enriched tumors $[38,40,42]$ and luminal B tumors $[40,42]$, whereas the long-term risk was greater in the luminal subtypes $[38,40,42]$. Interestingly, a second peak of late recurrences was also observed in the HER2 phenotypes $[38,42]$. No data regarding differences that depend on the Ki-67 value are available, except those reported by Keam et al. [41]. Those authors analyzed a series of 109 triple-negative patients and used a Ki-67 cutoff of 10 . Similar to our results, the low Ki-67 group showed a steady pattern and the high Ki-67 group displayed a sharp recurrence peak at 12 months.

The first peak of early relapses has been associated with surgery because the removal of the primary tumor could trigger the growth of clinically unapparent dormant micrometastatic foci [43]. Surgery could promote 
Table 9 Intrinsic subtype recurrence hazard rates over time and hazard ratios (six-marker definition) ${ }^{\text {a }}$

\begin{tabular}{|c|c|c|c|c|c|c|c|c|c|c|c|c|}
\hline $\begin{array}{l}\text { Years } \\
\text { after } \\
\text { surgery }\end{array}$ & $\begin{array}{c}\text { Luminal } A \\
\text { hazard rate }\end{array}$ & HR & $\begin{array}{l}\text { Luminal } B \\
\text { hazard rate }\end{array}$ & HR & $\begin{array}{c}\text { Luminal HER2 } \\
\text { hazard rate }\end{array}$ & HR & $\begin{array}{l}\text { HER2-enriched } \\
\text { hazard rate }\end{array}$ & HR & $\begin{array}{c}\text { Basal-like } \\
\text { hazard rate }\end{array}$ & HR & $\begin{array}{l}\text { TNP nonbasal } \\
\text { hazard rate }\end{array}$ & HR \\
\hline 2 & $4(0.2$ to 0.3$)$ & 1 & 0.50 (0.4 to 0.6$)$ & 2.05 & 0.56 (0.3 to 0.9$)$ & 2.30 & 1.83 (1.1 to 3.1$)$ & 7.53 & 0.84 (0.6 to 1.2$)$ & 3.46 & 0.60 (0.3 to 1.1$)$ & 2.46 \\
\hline 3 & 0.32 (0.2 to 0.4$)$ & 1 & 0.54 (0.4 to 0.6$)$ & 1.68 & 0.46 (0.2 to 0.8$)$ & 1.43 & 0.45 (0.1 to 1.4$)$ & 1.41 & 0.58 (0.4 to 0.8 ) & 1.83 & 0.66 (0.4 to 1.1$)$ & 2.06 \\
\hline 4 & 0.33 (0.2 to 0.4$)$ & 1 & 0.43 (0.3 to 0.5$)$ & 1.32 & 0.27 (0.1 to 0.5$)$ & 0.82 & 0.41 (0.1 to 1.6) & 1.27 & 0.29 (0.2 to 0.5$)$ & 0.90 & 0.60 (0.3 to 1.1$)$ & 1.84 \\
\hline 5 & 0.29 (0.2 to 0.3$)$ & 1 & 0.29 (0.2 to 0.4$)$ & 1.00 & 0.20 (0.07 to 0.5$)$ & 0.68 & 0.32 (0.06 to 1.6) & 1.09 & 0.14 (0.05 to 0.3$)$ & 0.47 & 0.51 (0.3 to 1.0$)$ & 1.75 \\
\hline 6 & 0.26 (0.1 to 0.3 ) & 1 & 0.26 (0.1 to 0.4$)$ & 1.02 & 0.19 (0.05 to 0.6$)$ & 0.72 & 0.55 (0.1 to 2.2 ) & 2.12 & 0.08 (0.03 to 0.2 ) & 0.29 & 0.39 (0.2 to 0.9$)$ & 1.51 \\
\hline 7 & 0.21 (0.1 to 0.3 ) & 1 & 0.31 (0.2 to 0.5$)$ & 1.43 & 0.13 (0.03 to 0.5$)$ & 0.59 & NA & NA & 0.05 (0.01 to 0.3 ) & 0.24 & 0.25 (0.08 to 0.8$)$ & 1.16 \\
\hline 8 & 0.18 (0.1 to 0.2$)$ & 1 & 0.35 (0.2 to 0.6$)$ & 1.95 & 0.01 (0.00 to 0.04$)$ & 0.06 & NA & NA & 0.09 (0.02 to 0.3$)$ & 0.49 & 0.15 (0.04 to 0.6$)$ & 0.86 \\
\hline 9 & 0.16 (0.1 to 0.3 ) & 1 & 0.38 (0.2 to 0.7$)$ & 2.33 & NA & NA & NA & NA & 0.14 (0.04 to 0.4$)$ & 0.84 & 0.05 (0.01 to 0.2 ) & 0.30 \\
\hline 10 & 0.21 (0.1 to 0.3 ) & 1 & 0.28 (0.1 to 0.6$)$ & 1.33 & NA & NA & NA & NA & 0.21 (0.08 to 0.6 ) & 1.00 & NA & NA \\
\hline
\end{tabular}

${ }^{\mathrm{a}} \mathrm{HER} 2$, human epidermal growth factor receptor $2 ; \mathrm{HR}$, hazard ratio; NA, not available; TNP, triple-negative phenotype. ${ }^{\mathrm{b}}$ Reference value. Note: $95 \%$ confidence interval is represented between the parentheses.

the growth of micrometastatic disease through several processes, such as an alteration in the angiogenic balance $[43,44]$, surgical stress-induced neuroendocrine activation [45] or alteration of the immune response $[46,47]$. These mechanisms could influence particularly the disease course in intrinsic subtypes with high expression of proliferation pathways, such as HER2 or basallike tumors. An increase of proliferation has been reported in HER2-positive patients with positive tumor margins after conservative surgery between the first and second tumor samples, as determined using Ki-67 immunohistochemistry, but this was not the case with HER2-negative cases [48].

The information provided by the study of the patterns of recurrence in early breast cancer would benefit patients in different ways. In this regard, our results could generate several hypotheses that, if confirmed in prospective randomized trials, would have noteworthy practical value. First of all, the surveillance after initial treatment could be fit to the expected recurrence pattern based on each intrinsic subtype. More important, however, is that the adjuvant treatment could be tailored more accurately according to each intrinsic subtype. Patients with tumors with high proliferation rates, such as HER2-enriched or basal-like, would benefit from more aggressive chemotherapy schedules (for example, dosedense). Such types of chemotherapy could avoid some of the recurrences that appear during the first peak. Also, in these cases with high expression of proliferation pathways, treatment with novel inhibitors of the cell cycle (for example, palbociclib) could be especially useful. In addition, those patients with luminal HER2 subtype could benefit from a second treatment with trastuzumab to decrease the second peak of recurrence.

The essential strengths of our study are the detailed and careful analysis of BCFS data, which describes a specific relapse pattern for every intrinsic subtype as a whole and is distinguished by the level of proliferation pathway activation in a homogeneously managed series of patients representing a full spectrum of breast cancers, which is not always available in clinical trial-based samples. The main limitation of our study is the lack of availability of tumor samples from all patients. It could be argued that the use of different schemes of adjuvant chemotherapy could have caused less consistency in our results. Evidence from the studies that initially described the special recurrence pattern of early breast cancer suggest that the structure of this pattern is the same, regardless of the type of adjuvant therapy used [16-18]. In this regard, the only change we observed was the height of the recurrence peaks, but not their number or their shape. Data from a patient series in Milan, Italy $[17,18]$, and from Eastern Cooperative Oncology Group coordinated studies [16], including patients treated only with surgery and patients treated with surgery plus several schemes of adjuvant chemotherapy, reproduced this recurrence structure with robustness.

The proliferation pathway plays a key role in the development of early recurrence after surgery in breast cancer, regardless of the intrinsic subtype involved. This conclusion is reinforced by the fact that our data were obtained by following a different statistical approach to survival analyses. Our results need to be corroborated in larger series of patients treated with current adjuvant systemic therapies; however, transferring knowledge regarding temporary patterns of recurrence in the development and design of future clinical trials in the adjuvant setting could be considered in establishing the timing or schedule of treatment administration that would be more effective. In addition, our data could have some impact on recommendations concerning patient follow-up. 


\section{Conclusions}

Breast cancer intrinsic subtypes using both four- and sixmarker immunohistochemical panels and proliferation assessed by using Ki-67 were determined in a large and homogeneous cohort of patients collected prospectively. Our most important findings are that each intrinsic subtype displayed a specific pattern of recurrence and that the proliferation pathway played a key role in the development of early recurrence. These results point directly to adjuvant treatment approaches and clinical follow-up schedules for surveillance, suggesting that both should be different, depending on intrinsic subtype. Moreover, understanding of these distinct clinical patterns of relapse may lead to new biological insights into the development and management of breast cancer.

\section{Abbreviations}

BCFS: Breast cancer-free survival; CISH: Chromogenic in situ hybridization; CK: Cytokeratin; EGFR: Epidermal growth factor receptor; ER: Estrogen receptor; HER2: Human epidermal growth factor receptor 2; PR: Progesterone receptor; TNP nonbasal: Triple-negative nonbasal phenotype.

\section{Competing interests}

The authors declare that they have no competing interests.

\section{Authors' contributions}

$E A, N R$ and JMJ contributed to the conception and design of the study. LPV, $L V, V L, E G$ and MA contributed to the tissue microarray construction and immunohistochemical scoring. BP, BJ, NR, AM, ASM and LPR contributed to the acquisition and assembly of clinical data. EA, NR, JMJ and LF contributed to the analysis and interpretation of the data. NR, JMJ and EA contributed to the drafting of the manuscript. All authors approved the final manuscript.

\section{Acknowledgments}

The authors thank Jose Manuel Trigo, MD, for his critical review and kind suggestions about the manuscript. This work was supported by Grant-in Aid PI081797 from the Ministry of Science and Innovation of Spain (Fondo de Investigaciones Sanitarias). The authors acknowledge funding through grants TIN2010-16556 (MICINN-Spain), TIC-4026/2008 (Consejería de Innovación, Ciencia y Empresa, Junta de Andalucía) and PI-0310/2008 (Consejería de Salud. Junta de Andalucía), all of which include European Regional Development Fund support.

\section{Author details \\ 'Department of Medical Oncology, Hospital Universitario Virgen de la Victoria, Campus Teatinos s/n, 29010 Málaga, Spain. ${ }^{2}$ Department of Pathology, Hospital Universitario Virgen de la Victoria, Campus Teatinos s/n, 29010 Málaga, Spain. ²Department of Languages and Computer Science, University of Malaga, Campus Teatinos s/n, 29010 Málaga, Spain. \\ ${ }^{4}$ Department of Pathology, University of Malaga, Campus Teatinos s/n, 29010 Málaga, Spain.}

Received: 30 April 2013 Accepted: 7 October 2013 Published: 22 October 2013

\section{References}

1. Perou CM, Sørlie T, Eisen MB, van de Rijn M, Jeffrey SS, Rees CA, Pollack JR, Ross DT, Johnsen $H$, Akslen LA, Fluge O, Pergamenschikov A, Williams C, Zhu SX, Lønning PE, Børresen-Dale AL, Brown PO, Botstein D: Molecular portraits of human breast tumours. Nature 2000, 406:747-752.

2. Sorlie T, Tibshirani R, Parker J, Hastie T, Marron JS, Nobel A, Deng S, Johnsen H, Pesich R, Geisler S, Demeter J, Perou CM, Lønning PE, Brown PO, Børresen-Dale AL, Botstein D: Repeated observation of breast tumor subtypes in independent gene expression data sets. Proc Natl Acad Sci USA 2003, 100:8418-8423.

3. Prat A, Perou CM: Deconstructing the molecular portraits of breast cancer. Mol Oncol 2011, 5:5-23.
4. Wirapati P, Sotiriou C, Kunkel S, Farmer P, Pradervand S, Haibe-Kains B, Desmedt C, Ignatiadis M, Sengstag T, Schütz F, Goldstein DR, Piccart M, Delorenzi M: Meta-analysis of gene expression profiles in breast cancer: toward a unified understanding of breast cancer subtyping and prognosis signatures. Breast Cancer Res 2008, 10:R65.

5. Haibe-Kains B, Desmedt C, Loi S, Culhane AC, Bontempi G, Quackenbush J, Sotiriou C: A three-gene model to robustly identify breast cancer molecular subtypes. J Natl Cancer Inst 2012, 104:311-325.

6. Hugh J, Hanson J, Cheang MC, Nielsen TO, Perou CM, Dumontet C, Reed J, Krajewska M, Treilleux I, Rupin M, Magherini E, Mackey J, Martin M, Vogel C: Breast cancer subtypes and response to docetaxel in node-positive breast cancer: use of an immunohistochemical definition in the BCIRG 001 trial. J Clin Oncol 2009, 27:1168-1176.

7. Cancello G, Maisonneuve P, Rotmensz N, Viale G, Mastropasqua MG, Pruneri G, Veronesi P, Torrisi R, Montagna E, Luini A, Intra M, Gentilini O, Ghisini R, Goldhirsch A, Colleoni M: Prognosis and adjuvant treatment effects in selected breast cancer subtypes of very young women ( $<35$ years) with operable breast cancer. Ann Oncol 2010, 21:1974-1981.

8. Nielsen TO, Parker JS, Leung S, Voduc D, Ebbert M, Vickery T, Davies SR, Snider J, Stijleman IJ, Reed J, Cheang MC, Mardis ER, Perou CM, Bernard PS, Ellis MJ: A comparison of PAM50 intrinsic subtyping with immunohistochemistry and clinical prognostic factors in tamoxifentreated estrogen receptor-positive breast cancer. Clin Cancer Res 2010, 16:5222-5232

9. Cuzick J, Dowsett M, Pineda S, Wale C, Salter J, Quinn E, Zabaglo L, Mallon E, Green AR, Ellis IO, Howell A, Buzdar AU, Forbes JF: Prognostic value of a combined estrogen receptor, progesterone receptor, $\mathrm{Ki}-67$, and human epidermal growth factor receptor 2 immunohistochemical score and comparison with the Genomic Health recurrence score in early breast cancer. J Clin Oncol 2011, 29:4273-4278.

10. Montagna E, Bagnardi V, Rotmensz N, Viale G, Renne G, Cancello G, Balduzzi A, Scarano E, Veronesi P, Luini A, Zurrida S, Monti S, Mastropasqua MG, Bottiglieri L, Goldhirsch A, Colleoni M: Breast cancer subtypes and outcome after local and regional relapse. Ann Oncol 2012, 23:324-331.

11. Cheang MC, Voduc D, Bajdik C, Leung S, McKinney S, Chia SK, Perou CM Nielsen TO: Basal-like breast cancer defined by five biomarkers has superior prognostic value than triple-negative phenotype. Clin Cancer Res 2008, 14:1368-1376

12. Cheang MC, Chia SK, Voduc D, Gao D, Leung S, Snider J, Watson M, Davies S, Bernard PS, Parker JS, Perou CM, Ellis MJ, Nielsen TO: Ki67 index, HER2 status, and prognosis of patients with luminal B breast cancer. J Natl Cancer Inst 2009, 101:736-750.

13. Kennecke $H$, Yerushalmi R, Woods R, Cheang MC, Voduc D, Speers $C H$, Nielsen TO, Gelmon K: Metastatic behavior of breast cancer subtypes. J Clin Oncol 2010, 28:3271-3277.

14. Voduc KD, Cheang MC, Tyldesley S, Gelmon K, Nielsen TO, Kennecke H: Breast cancer subtypes and the risk of local and regional relapse. J Clin Oncol 2010, 28:1684-1691.

15. Martín M, Rodríguez-Lescure A, Ruiz A, Alba E, Calvo L, Ruiz-Borrego M, Santaballa A, Rodríguez CA, Crespo C, Abad M, Domínguez S, Florián J, Llorca C, Méndez M, Godes M, Cubedo R, Murias A, Batista N, García MJ, Caballero R, de Alava E: Molecular predictors of efficacy of adjuvant weekly paclitaxel in early breast cancer. Breast Cancer Res Treat 2010, 123:149-157.

16. Saphner T, Tormey DC, Gray R: Annual hazard rates of recurrence for breast cancer after primary therapy. J Clin Oncol 1996, 14:2738-2746.

17. Demicheli R, Abbattista A, Miceli R, Valagussa P, Bonadonna G: Time distribution of the recurrence risk for breast cancer patients undergoing mastectomy: further support about the concept of tumor dormancy. Breast Cancer Res Treat 1996, 41:177-185.

18. Demicheli R, Miceli R, Brambilla C, Ferrari L, Moliterni A, Zambetti M, Valagussa P, Bonadonna G: Comparative analysis of breast cancer recurrence risk for patients receiving or not receiving adjuvant cyclophosphamide, methotrexate, fluorouracil (CMF): data supporting the occurrence of 'cures'. Breast Cancer Res Treat 1999, 53:209-215.

19. Karrison TG, Ferguson DJ, Meier P: Dormancy of mammary carcinoma after mastectomy. J Natl Cancer Inst 1999, 91:80-85.

20. Jatoi I, Tsimelzon A, Weiss H, Clark GM, Hilsenbeck SG: Hazard rates of recurrence following diagnosis of primary breast cancer. Breast Cance Res Treat 2005, 89:173-178. 
21. Dignam JJ, Dukic V, Anderson SJ, Mamounas EP, Wickerham DL, Wolmark $\mathrm{N}$ : Hazard of recurrence and adjuvant treatment effects over time in lymph node-negative breast cancer. Breast Cancer Res Treat 2009, 116:595-602.

22. Demicheli R, Biganzoli E, Ardoino I, Boracchi P, Coradini D, Greco M, Moliterni A, Zambetti M, Valagussa P, Gukas ID, Bonadonna G: Recurrence and mortality dynamics for breast cancer patients undergoing mastectomy according to estrogen receptor status: different mortality but similar recurrence. Cancer Sci 2010, 101:826-830.

23. Nielsen TO, Hsu FD, Jensen K, Cheang M, Karaca G, Hu Z, HernandezBoussard T, Livasy C, Cowan D, Dressler L, Akslen LA, Ragaz J, Gown AM, Gilks CB, van de Rijn M, Perou CM: Immunohistochemical and clinical characterization of the basal-like subtype of invasive breast carcinoma. Clin Cancer Res 2004, 10:5367-5374.

24. Wolff AC, Hammond ME, Schwartz JN, Hagerty KL, Allred DC, Cote RJ, Dowsett M, Fitzgibbons PL, Hanna WM, Langer A, McShane LM, Paik S, Pegram MD, Perez EA, Press MF, Rhodes A, Sturgeon C, Taube SE, Tubbs R Vance $\mathrm{GH}$, van de Vijver M, Wheeler TM, Hayes DF, American Society of Clinical Oncology; College of American Pathologists: American Society of Clinical Oncology/College of American Pathologists guideline recommendations for human epidermal growth factor receptor 2 testing in breast cancer. J Clin Oncol 2007, 25:118-145.

25. Hammond ME, Hayes DF, Dowsett M, Allred DC, Hagerty KL, Badve S, Fitzgibbons PL, Francis G, Goldstein NS, Hayes M, Hicks DG, Lester S, Love R, Mangu PB, McShane L, Miller K, Osborne CK, Paik S, Perlmutter J, Rhodes A Sasano H, Schwartz JN, Sweep FC, Taube S, Torlakovic EE, Valenstein P, Viale G, Visscher D, Wheeler T, Williams RB, Wittliff JL, Wolff AC: American Society of Clinical Oncology/College of American Pathologists guideline recommendations for immunohistochemical testing of estrogen and progesterone receptors in breast cancer. J Clin Oncol 2010, 28:2784-2795. A published erratum appears in $J$ Clin Oncol 2010, 28:3543.

26. Zabaglo L, Salter J, Anderson H, Quinn E, Hills M, Detre S, A'Hern R, Dowsett M: Comparative validation of the SP6 antibody to Ki67 in breast cancer. J Clin Pathol 2010, 63:800-804.

27. http://www.r-project.org/

28. Akaike $\mathrm{H}$ : A new look at the statistical model identification. IEEE Trans Automat Contr 1974, 19:716-723.

29. Hess KR, Serachitopol DM, Brown BW: Hazard function estimators: a simulation study. Stat Med 1999, 18:3075-3088.

30. McShane LM, Altman DG, Sauerbrei W, Taube SE, Gion M, Clark GM, Statistics Subcommittee of the NCl-EORTC Working Group on Cancer Diagnostics: Reporting recommendations for tumor marker prognostic studies (REMARK). J Natl Cancer Inst 2005, 97:1180-1184.

31. Aleskandarany MA, Green AR, Benhasouna AA, Barros FF, Neal K, Reis-Filho $J S$, Ellis IO, Rakha EA: Prognostic value of proliferation assay in the luminal, HER2-positive, and triple-negative biologic classes of breast cancer. Breast Cancer Res 2012, 14:R3.

32. Carey LA, Dees EC, Sawyer L, Gatti L, Moore DT, Collichio F, Ollila DW, Sartor $\mathrm{Cl}$, Graham ML, Perou CM: The triple negative paradox: primary tumor chemosensitivity of breast cancer subtypes. Clin Cancer Res 2007, 13:2329-2334

33. Dent R, Hanna WM, Trudeau M, Rawlinson E, Sun P, Narod SA: Pattern of metastatic spread in triple-negative breast cancer. Breast Cancer Res Treat 2009, 115:423-428.

34. Liedtke C, Mazouni C, Hess KR, André F, Tordai A, Mejia JA, Symmans WF, Gonzalez-Angulo AM, Hennessy B, Green M, Cristofanilli M, Hortobagyi GN, Pusztai L: Response to neoadjuvant therapy and long-term survival in patients with triple-negative breast cancer. J Clin Oncol 2008, 26:12751281.

35. Mulligan AM, Pinnaduwage D, Bull SB, O'Malley FP, Andrulis IL: Prognostic effect of basal-like breast cancers is time dependent: evidence from tissue microarray studies on a lymph node-negative cohort. Clin Cancer Res 2008, 14:4168-4174.

36. Rhee J, Han SW, Oh DY, Kim JH, Im SA, Han W, Park IA, Noh DY, Bang YJ, Kim TY: The clinicopathologic characteristics and prognostic significance of triple-negativity in node-negative breast cancer. BMC Cancer 2008, 8:307.

37. Nofech-Mozes S, Trudeau M, Kahn HK, Dent R, Rawlinson E, Sun P, Narod SA, Hanna WM: Patterns of recurrence in the basal and non-basal subtypes of triple-negative breast cancers. Breast Cancer Res Treat 2009, 118:131-137.
38. Yin W, Di G, Zhou L, Lu J, Liu G, Wu J, Shen K, Han Q, Shen Z, Shao Z: Timevarying pattern of recurrence risk for Chinese breast cancer patients. Breast Cancer Res Treat 2009, 114:527-535.

39. Dent R, Trudeau M, Pritchard KI, Hanna WM, Kahn HK, Sawka CA, Lickley LA, Rawlinson E, Sun P, Narod SA: Triple-negative breast cancer: clinical features and patterns of recurrence. Clin Cancer Res 2007, 13:4429-4434.

40. Jatoi I, Anderson WF, Jeong JH, Redmond CK: Breast cancer adjuvant therapy: time to consider its time-dependent effects. J Clin Oncol 2011, 29:2301-2304

41. Keam B, Im SA, Lee KH, Han SW, Oh DY, Kim JH, Lee SH, Han W, Kim DW, Kim TY, Park IA, Noh DY, Heo DS, Bang YJ: Ki-67 can be used for further classification of triple negative breast cancer into two subtypes with different response and prognosis. Breast Cancer Res 2011, 13:R22.

42. Brouckaert O, Laenen A, Vanderhaegen J, Wildiers H, Leunen K, Amant F, Berteloot P, Smeets A, Paridaens R, Christiaens MR, Floris G, Moerman P, Van Limbergen E, Peeters S, Weltens C, Vergote I, Neven P: Applying the 2011 St Gallen panel of prognostic markers on a large single hospital cohort of consecutively treated primary operable breast cancers. Ann Oncol 2013, 23:2578-2584.

43. Demicheli R, Retsky MW, Hrushesky WJ, Baum M, Gukas ID: The effects of surgery on tumor growth: a century of investigations. Ann Oncol 2008, 19:1821-1828.

44. Baum M, Demicheli R, Hrushesky W, Retsky M: Does surgery unfavourably perturb the "natural history" of early breast cancer by accelerating the appearance of distant metastases? Eur J Cancer 2005, 41:508-515.

45. Sloan EK, Priceman SJ, Cox BF, Yu S, Pimentel MA, Tangkanangnukul V, Arevalo JM, Morizono K, Karanikolas BD, Wu L, Sood AK, Cole SW: The sympathetic nervous system induces a metastatic switch in primary breast cancer. Cancer Res 2010, 70:7042-7052.

46. Goldfarb Y, Ben-Eliyahu S: Surgery as a risk factor for breast cancer recurrence and metastasis: mediating mechanisms and clinical prophylactic approaches. Breast Dis 2006-2007, 26:99-114.

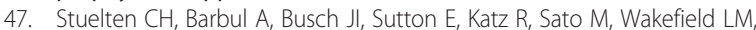
Roberts $A B$, Niederhuber JE: Acute wounds accelerate tumorigenesis by a T cell-dependent mechanism. Cancer Res 2008, 68:7278-7282.

48. Tagliabue E, Agresti R, Carcangiu ML, Ghirelli C, Morelli D, Campiglio M, Martel M, Giovanazzi R, Greco M, Balsari A, Ménard S: Role of HER2 in wound-induced breast carcinoma proliferation. Lancet 2003, 362:527-533.

\section{doi:10.1186/bcr3559}

Cite this article as: Ribelles et al: Pattern of recurrence of early breast cancer is different according to intrinsic subtype and proliferation index. Breast Cancer Research 2013 15:R98.

\section{Submit your next manuscript to BioMed Central and take full advantage of:}

- Convenient online submission

- Thorough peer review

- No space constraints or color figure charges

- Immediate publication on acceptance

- Inclusion in PubMed, CAS, Scopus and Google Scholar

- Research which is freely available for redistribution 